RACHEL HYDE

\title{
DOMESTIC WORKERS IN NEW ZEALAND AND THE IMPLICATIONS OF INTERNATIONAL LABOUR ORGANIZATION CONVENTION NO 189
}

\author{
LLB(HONS)
}

LAWS524: HUMAN RIGHTS RESEARCH PAPER

\section{FACULTY OF LAW}

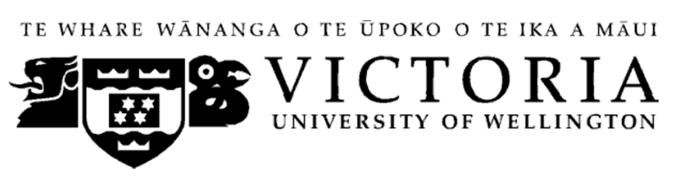

2013 


\section{Contents}

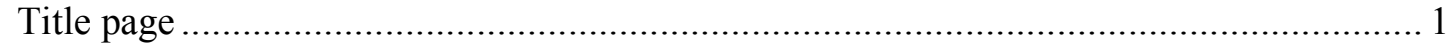

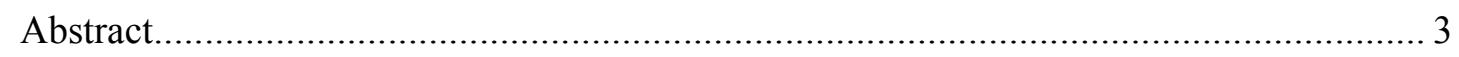

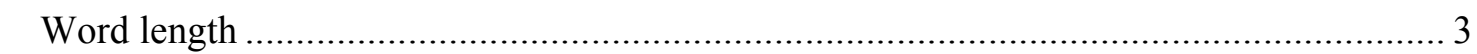

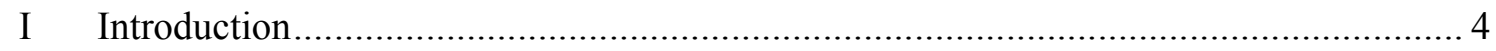

II Defining Domestic Workers ............................................................................... 5

III A Picture of Domestic Work............................................................................... 7

A Domestic Work as a Global Phenomenon .................................................................. 7

B The Public/Private Divide and Domestic Work ....................................................... 9

IV The International Labour Organisation Domestic Workers Convention ...................... 15

A The promotion and protection of human rights................................................... 15

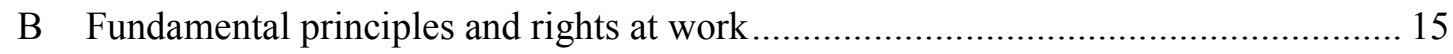

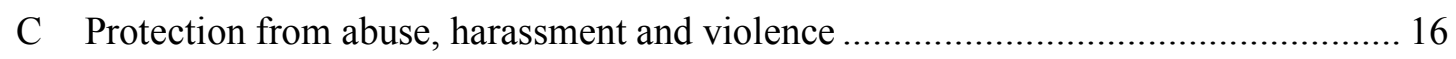

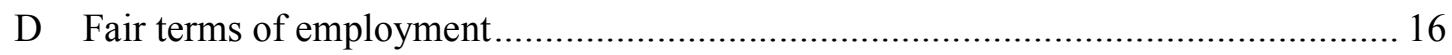

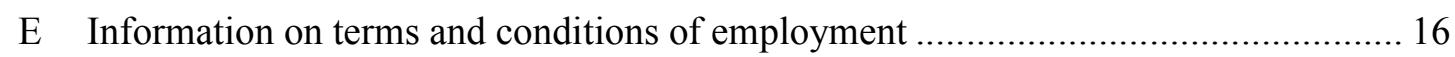

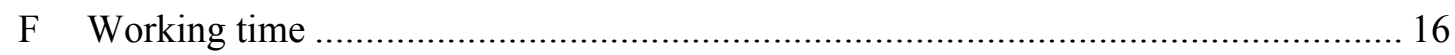

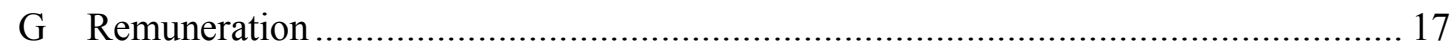

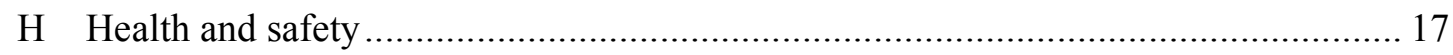

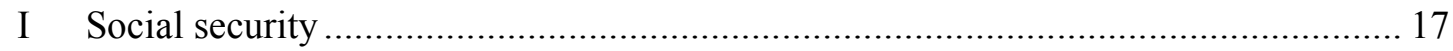

J Protection for particular groups of domestic workers .......................................... 17

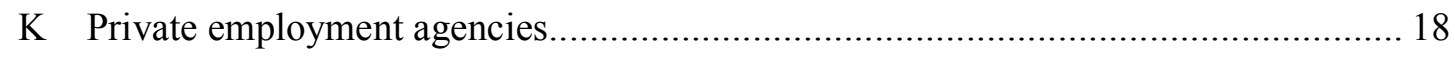

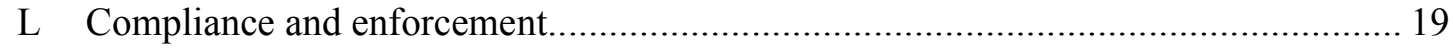

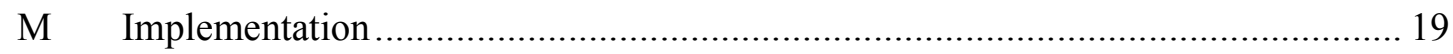

$\mathrm{N}$ New Zealand and the Domestic Worker Convention............................................. 20

$\mathrm{V}$ The New Zealand Statutory Scheme ................................................................ 23

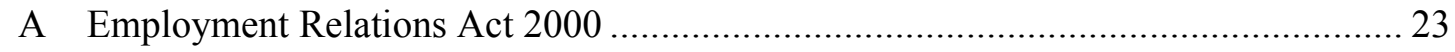

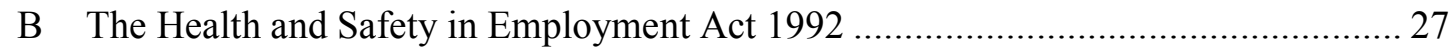

C Domestic Workers in Other New Zealand Legislation ......................................... 30

D The Human Rights Act 1993 .......................................................................... 30

VI Does New Zealand Law Meet the Requirements of Convention No 189? ................... 34

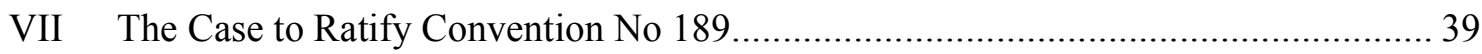

A Through the Lens of the Aged-Care Sector ......................................................... 39

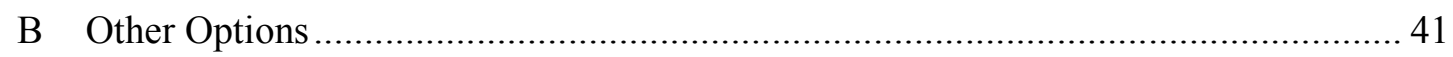

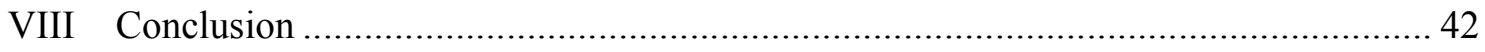

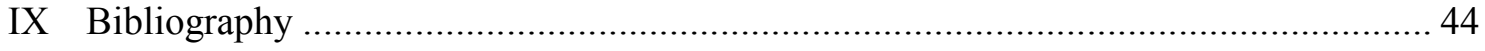




\begin{abstract}
There are an estimated 52.6 million domestic workers in the world, 83 per cent of whom are women, and many of whom work in poor conditions for low pay. Globally, domestic work is an under-regulated and under-valued sector. In an effort to address the precariousness of domestic work, the International Labour Organization adopted Convention No 189, concerning decent work for domestic workers. The Convention came into force on 5 September 2013. It provides for global minimum standards in areas in respect to which domestic workers should enjoy employment and social protection.

The rights of domestic workers in New Zealand are addressed in a number of pieces of legislation, including the Employment Relations Act 2000, the Health and Safety in Employment Act 1992, and the Human Rights Act 1993. Although some categories of domestic worker receive protection under the legislation, others do not. This paper argues that the coverage of domestic workers in New Zealand is confusing and incomplete. For many domestic workers in New Zealand low pay and poor working conditions are a reality.

If New Zealand's domestic workers are to receive the same protection as other New Zealand employees and those domestic workers in nations that have ratified Convention No 189, then

ratification of the Convention and associated domestic legislative change may be necessary to bring domestic law into line with international labour law. In the absence of ratification there are a number of options that could be pursued to improve the working lives of domestic workers in New Zealand.
\end{abstract}

\title{
Word length
}

The text of this paper (excluding abstract, table of contents, footnotes and bibliography) comprises approximately 14,572 words.

\section{Subjects and Topics}

ILO Convention No 189

Domestic Workers

Employment Relations Act 2000-Health and Safety in Employment Act 1992-Human Rights Act 1993 


\section{Introduction}

In recent years, domestic workers have been the subject of unprecedented international attention, resulting from the adoption in 2011 of a new International Labour Organisation ("ILO") convention and recommendation which aim to protect and enhance the rights of domestic workers around the world. ${ }^{1}$ Convention No 189 (“C189"), concerning decent work for domestic workers, is the ILO's first attempt to formulate international labour standards dedicated to this group of workers, ${ }^{2}$ and its adoption demonstrates a shift in policy thinking on the domestic work sector at an international level. ${ }^{3}$ The adoption of Convention No 189 has also led to the plight of New Zealand's domestic workers receiving increased attention. ${ }^{4}$

According to the most recent estimates produced by the ILO, at least 52.6 million adult workers are domestic workers in their main job, representing 3.6 per cent of global wage employment. ${ }^{5} 83$ per cent of the domestic worker workforce is women, accounting for 7.5 per cent of female employees worldwide. ${ }^{6}$ Domestic workers therefore makeup a considerable portion of the workforce, and their number is increasing. ${ }^{7}$ However despite its economic and social significance, domestic work is undervalued and poorly regulated, with many domestic workers suffering from overwork, underpay and maltreatment. ${ }^{8}$ Part of the reason for this state of affairs is the fact that domestic work is perceived as occurring in a 'private sphere' that is outside the reach of state regulation. ${ }^{9}$

Convention No 189 establishes a set of minimum standards and requires member States to "ensure the effective promotion and protection of the human rights of all domestic workers". ${ }^{10}$ In this paper I will ask whether New Zealand should ratify Convention No 189. This is not an easy question, as it requires the balancing of two competing sets of rights - the employment and human rights of domestic workers and the right of their employers to

\footnotetext{
${ }^{1}$ See generally "World's 53 million domestic workers often exploited: UN" (9 January 2013) CBC News $<$ www.cbc.ca>, Donna Hussey-Whyte "Domestic workers now have their own union" (18 March 2013) Jamaica Observer $<$ www.jamaicaobserver.com $>$, Patrick Camara Ropeta "Domestic workers use arts to voice rights in Europe" (27 April 2013) ABS-CBN News <www.abs-cbnnews.com>.

${ }^{2}$ International Labour Office Effective Protection for Domestic Workers: A Guide to Designing Labour Laws (2011), at ix.

${ }^{3}$ At 6 .

4 See generally " "Slaves' tell of $\$ 40$ for 7 days work" (7 June 2012) Stuff.co.nz <www.stuff.co.nz>, "Union women focus on domestic workers" (8 March 2012) Voxy <www.voxy.co.nx>, Gordon Anderson "ILO Convention on domestic workers" (21 June 2011) New Zealand Employment Law.

$<$ labourlawnz.blogspot.co.nz> and "NZ vote at ILO fails domestic workers" (9 June 2010) Human Rights Commission $<$ www.hrc.org.nz $>$.

${ }^{5}$ International Labour Office Domestic Workers Across the World: Global and Regional Statistics and the Extent of Legal Protection (International Labour Office, Geneva, 2013) at 19.

${ }^{6}$ At 19.

${ }^{7}$ International Labour Office Decent Work for Domestic Workers Report IV(1) (2010) at 1.

${ }^{8}$ At 1 .

${ }^{9}$ At 1 .

${ }^{10}$ International Labour Organisation Convention Concerning Decent Work for Domestic Workers Convention 189 (opened for signature 16 June 2011, entered into force 5 September 2013), art 3(1).
} 
privacy and autonomy. Additionally, protecting this vulnerable group of worker requires the law to reach into an area of life that has traditionally been seen as beyond state regulation the private home. For centuries the balance has been weighted in favour of the rights of the employer, to the disadvantage of domestic workers. The adoption of Convention No 189 may finally lead to shift in how these competing rights are balanced, and an acknowledgement that the law does not necessarily end at the front door.

I will begin in Part II by defining domestic workers for the purposes of this paper, before describing the global phenomenon of domestic work in Part III. In Part IV, I will set out the requirements of Convention No 189 and describe New Zealand's involvement in the preparation and adoption of the Convention. I will then unravel the New Zealand statutory scheme in relation to domestic workers in Part V, before going on in Part VI to compare the protection received by domestic workers under New Zealand's domestic legislation with the requirements of Convention No 189.

Finally, in Part VII, I will make a case for New Zealand ratifying Convention No 189 with reference to the needs of the aged-care workforce. I will suggest that although New Zealand should ratify the Convention, it is unlikely to do so due to the significant implications ratification would have in terms of amending domestic legislation. I will conclude by offering alternatives to ratification of Convention No 189 that could go at least some way to improving the working lives of New Zealand's domestic workers.

\section{Defining Domestic Workers}

Defining domestic workers is not a simple task, as domestic workers are anything but a homogenous group. ${ }^{11}$ There are variants in their demographic profile, including gender, age and migration status. The nature of the employment relationship can also vary, with the workforce including full- and part-time employees and workers in both the formal and informal economies. Whilst some domestic workers live in their employers' residence, others live in their own homes. The nature of their job also reveals the complexity of defining domestic workers, as they typically perform tasks as varied as cleaning, cooking, washing and ironing, taking care of children, elderly or sick members of a family, gardening, guarding the house and driving for the family. ${ }^{12}$

The definition of domestic worker used in this paper is that devised for use in C189, which draws on the single common feature of all domestic workers: that they work for private households. ${ }^{13} \mathrm{C} 189$ defines domestic workers as "any person engaged in domestic work

\footnotetext{
${ }^{11}$ International Labour Office, above n 5, at 7.

${ }^{12}$ International Labour Office, above n 5, at 7.

${ }^{13}$ International Labour Office, above n 5, at 7.
} 
within an employment relationship". ${ }^{14}$ Domestic work is defined as "work performed in or for a household or households". ${ }^{15}$ Domestic workers are those who engage in domestic work on an occupational basis, rather than those who perform domestic work only occasionally or sporadically. ${ }^{16}$

Having this globally accepted definition of domestic worker is of particular use when assessing the protections currently afforded to domestic workers under New Zealand law, as they are not defined in New Zealand legislation and do not exist as a discrete employment category.

There are four main ways in which domestic workers are employed in New Zealand: ${ }^{17}$

1. Direct employees of homeowner/occupier working in the employers' private home (“category 1" workers);

2. Employees of private employment agencies ("category 2" workers);

3. Employees of District Health Boards ("DHBs") looking after people in their own home ("category 3" workers); and

4. Self-employed contractors contracting directly with homeowners/occupiers or subcontracting to other funders, for example DHBs ("category 4" workers). An example of a category 4 worker in New Zealand is a "Mr Green" franchise-owner. "Mr Green" is a nationwide franchise-based company that offers in home and commercial cleaning, and garden and lawn care. "Mr Green" has 204 independent franchisees who are able to contract directly with homeowners as well as performing work supplied by the franchise group. ${ }^{18}$

Although the type of employment relationship may differ, the work undertaken and the location of the work (the private home), remain the same for each of these categories. For example, a cleaner may be employed directly by a homeowner, work for a cleaning agency, be self-employed as a franchise holder for "Mr Green", or work as an employee of a DHB cleaning the homes of elderly people. In each case the work involved is cleaning and the location is a private home.

\footnotetext{
${ }^{14}$ Article 1(a).

${ }^{15}$ Article 1(b).

${ }^{16}$ Article 1(c).

${ }^{17}$ Jessie Williams, Lisa Tortell and Paul Callister "The Mysterious Case of the Housemaid: Domestic Workers in New Zealand Law" [2009] NZ L Rev 695 at $701-702$.

18 “About Mr Green” (24 August 2013) Mr Green <www.mrgreen.co.nz>.
} 


\section{A Picture of Domestic Work}

A Domestic Work as a Global Phenomenon

Domestic work is one of the world's oldest occupations. ${ }^{19}$ Historically it has been linked to slavery, colonialism and many forms of servitude. ${ }^{20}$ In the 21 st century, domestic work is a global phenomenon. First-world economies utilise minority and immigrant workers who are willing to work in an undervalued and unregulated industry, whilst third-world states increasingly rely on remittances sent by these workers back to their country. ${ }^{21}$ The contemporary pattern of domestic work therefore perpetuates hierarchies based on gender, race, indigenous status and nationality. ${ }^{22}$

Global demand for domestic workers is increasing. Between 1995 and 2010 the number of domestic workers around the world rose from approximately 33.2 million to 52.6 million. ${ }^{23}$ The demand for domestic workers is driven by factors including the growing participation of women in the labour force, a lack of policies directed at balancing work and family life, the decline in state provision of care services, and the ageing of societies. ${ }^{24}$

The most recent ILO study of domestic workers estimates the number of adult domestic workers globally at 52.6 million, ${ }^{25} 83$ per cent of whom are women, representing 7.5 per cent of women's wage employment world-wide. ${ }^{26}$ There are also an estimated 10.5 million child labourers in domestic work globally. ${ }^{27}$

In New Zealand the prevalence of domestic work is difficult to discern. Domestic service was the single largest employment category for women until the $1930 \mathrm{~s},{ }^{28}$ and although it tailed off after the Second World War, the incidence of domestic work in New Zealand appears to be on the rise again. ${ }^{29}$ The difficulty is that there is no direct measure of the number of people employed in domestic work in New Zealand. New Zealand's industrial classification tool, the Australian and New Zealand Standard Industrial Classification 2006 (otherwise known as ANZSIC06), contains no single category which covers the full range of domestic work. Types of domestic work are captured by three distinct ANZSIC06 categories; Residential Care Services and Social Assistance (QQ113), Personal Care, Funeral and Other Personal

\footnotetext{
${ }^{19}$ International Labour Office, above n 7, at 1.

${ }^{20}$ International Labour Office, above n 7, at 5, and see Terri Nilliasca "Some Women's Work: Domestic Work, Class, Race, Heteropatriarchy, and the Limits of Legal Reform” (2011) 16 Mi JRL 377.

${ }^{21}$ International Labour Office, above $\mathrm{n} 7$, at 10, and Nilliasca, above $\mathrm{n} 5$, at 3 .

22 International Labour Office, above n 7, at 5.

${ }^{23}$ International Labour Office, above n 5, at 24.

${ }^{24}$ International Labour Office, above n 5, at 24.

${ }^{25}$ International Labour Office, above n 5, at 19.

${ }^{26}$ International Labour Office, above n 5, at 19.

${ }^{27}$ International Labour Office Ending Child Labour in Domestic Work and Protecting Young Workers from Abusive Working Conditions (International Labour Office, Geneva, 2013) at 1.

${ }^{28}$ Williams, Tortell and Callister, above, n 17, at 2.

${ }^{29}$ Paul Callister, Juthika Badkar and Jessie Williams Paid Caregivers and Domestic Workers: Some Policy Issues in Relation to Meeting Future Demand in New Zealand (2009) 5 Pol'y Quarterly 38 at 39.
} 
Services (RS212), and Private Households Employing Staff (RS215). As there is no indication of how many workers within each category are performing domestic work, it is impossible to accurately estimate the number of people engaged in domestic work in New Zealand.

This difficulty is compounded by the fact that there has been no national census since 2006, as the census scheduled for 2011 was postponed due to the Canterbury earthquakes. The 2006 census showed that there were 342 domestic housekeepers, 1,143 domestic cleaners and 2.702 nannies in New Zealand. A contrasting figure was reported in the ILO's 2013 report on domestic workers across the world. ${ }^{30}$ The figure was based on the 2008 Household Labour Force Survey conducted by Statistics New Zealand (using ANZSIC06), which reported 2,200 domestic workers, 2,100 of whom were women. Both the census figure and the Household Labour Force survey are likely to be undercounted, due to the probability of domestic work being unrecorded, the fact that domestic work may be secondary employment and so not captured by the surveys or because of the definitional issue with ANZSIC06 described above.

One area where it is clear that the number of domestic workers will increase in coming years is the aged-care industry. In 2006, aged-care workers represented around 1 per cent of the workforce (or 17,900 workers) ${ }^{31}$ with 92 per cent of the caregiving workforce being women. ${ }^{32}$ The Department of Labour has estimated that the number of caregivers needed to meet the demands of New Zealand's ageing population will rise from just under 18,000 in 2006 to over 24,000 in 2016 and 48,000 by $2036 .{ }^{33}$ This statistic alone suggests that New Zealand will follow the international trend of an upsurge in the numbers of domestic workers, and that the importance of domestic work will grow as population demographics continue to change.

Despite the significance of the industry, domestic work remains undervalued and underregulated. It is undervalued because it is seen as unskilled work that women are innately capable of (and suited to) doing. Domestic work is often described as something "other than employment", ${ }^{34}$ where domestic workers are 'one of the family' rather than employees, and the role of the person doing the hiring is decidedly not seen as that of an employer.

Domestic work is under-regulated because it is virtually invisible as a form of employment. ${ }^{35}$ The work place is the private home, which remains an area beyond the reach of the law in

\footnotetext{
${ }^{30}$ International Labour Office, above n 5, at 118.

${ }^{31}$ Juthika Badkar The Future Demand for Paid Caregivers in a Rapidly Ageing Society (Department of Labour, Wellington, 2009) at 18.

${ }^{32}$ At 16 .

${ }^{33}$ At 18 .

${ }^{34}$ International Labour Office, above n 7, at 12.

${ }^{35}$ International Labour Office, above n 7, at 1.
} 
many states, ${ }^{36}$ where the rights of domestic workers give way to the sanctity of the private family home. ${ }^{37}$ This situation is compounded because domestic workers usually work alone, without the support of co-workers and in the absence of employee organisations such as trade-unions or co-operatives. Additionally, in many parts of the world domestic work remains entrenched in the informal economy. This means that the worker is unlikely to have a written employment contract, whilst the employer will be free from any external monitoring because domestic work is likely to be excluded from employment legislation. ${ }^{38}$

Finally, some domestic workers remain hidden by choice (such as migrant domestic workers who wish to remain anonymous for reasons related to their migration status), whilst others have no choice at all (such as consciously hidden child labourers or victims of forced labour). ${ }^{39}$

The global picture of domestic work is therefore of an undervalued and poorly regulated industry with workers who are particularly vulnerable to exploitation and abuse. This is not a situation that has arisen recently however. Domestic workers have been in a precarious position for generations, and if their position is to be improved it will first be necessary to understand why domestic work is so undervalued and unregulated. Without this understanding, it is unlikely that any attempt to remedy the plight of domestic workers will be successful.

\section{B The Public/Private Divide and Domestic Work}

The precariousness of domestic work is specific to the nature of the domestic employment relationship, ${ }^{40}$ and in particular to the fact that domestic work has traditionally been treated as "work like no other". ${ }^{41}$ Despite the origins of the domestic worker/employer relationship going back to the "master-servant" relationship, the domestic employment relationship has been treated as something other than regular employment. ${ }^{42}$ Often employers of domestic workers will describe the worker as "one of the family" rather than as an employee. ${ }^{43}$ It is in this statement that we can begin to trace the origin of the precariousness of domestic work, and it leads us to the influence of the public/private divide on domestic work.

\footnotetext{
${ }^{36}$ International Labour Office, above n 2, at 2.

${ }^{37}$ Williams, Tortell and Callister, above $\mathrm{n} 17$, at 713.

${ }^{38}$ International Labour Office, above $\mathrm{n} 2$, at 2.

${ }^{39}$ Williams, Tortell and Callister above $\mathrm{n} 17$, at 700.

${ }^{40}$ Virginia Mantouvalou "Human Rights for Precarious Workers: The Legislative Precariousness of Domestic Labour” (2012 - 2013) 34 Comp Lab L \& Pol'y J 133.

${ }^{41}$ International Labour Office, above $\mathrm{n} 7$, at 12.

42 At 1.

${ }^{43}$ At 12.
} 
The concept of the public/private divide has been well traversed in recent decades, particularly with regard to state regulation of the family, and also in relation to the impact of international human rights law on women. ${ }^{44}$

In essence the argument is that there are two materially, and ideologically, distinct spheres in which we live our life: the public and the private. The origins of this divide can be traced back thousands of years, at least to the philosophy of Plato and his division of humankind into the oikos (the home or private) and the polites (or public). For Plato, the private world of the household, inhabited by women, children, slaves and servants, was accorded a much lower status than the public world, in which good men pursued a life of righteousness and justice. ${ }^{45}$ Plato's division can therefore be seen as the origin of the invisibility of domestic work.

An essential aspect of the origin of the separation of public and private spheres was their symbiosis. The inequality that epitomised the oikos was necessary for the master (the male) to have the freedom to participate within the polis. ${ }^{46}$ The divide between public and private spheres thus became crucial for the operation of political life. By the time of Aristotle, women had been fully subsumed into the non-public sphere of the household, leaving them with no public voice or role. ${ }^{47}$

Over the centuries the positioning of women as persons who could not, or did not, participate in public life became an inherent part of the social fabric. As philosophies changed, the rationale for women's subjugation changed, but their role and status did not. Even the coming of the liberal tradition and social contract theory did not release women from their private station, with Locke resorting to an argument on the basis of nature (a "result of the punishment laid upon Eve"48) to justify woman's subordination to man. ${ }^{49}$ Locke (and Hobbes) also developed the concept of a private 'sphere', which surrounded an individual (the public man) and protected him from other individuals and from interference by the state. ${ }^{50}$ The conflation of the private sphere really began at this point, as the private family sphere gradually became confused with the private sphere protecting an individual from state interference.

\footnotetext{
${ }^{44}$ See Frances E Olson "The Myth of State Intervention in the Family" (1984 - 1985) 18 U Mich J L Reform 835 and Hilary Charlesworth, Christine Chinking and Shelley Wright "Feminist Approaches to International Law" (1991) 85 Am J Intl L 613.

${ }^{45}$ Jean Bethke Elshtain Public Man, Private Woman: Women in Social and Political Thought (Martin Robertson, Oxford, 1981) at $22-23$.

${ }^{46}$ Margaret Thornton (ed) Public and Private: Feminist Legal Debates (Oxford University Press, Melbourne, $1995)$ at 3.

${ }^{47}$ Elshtain, above $\mathrm{n} 45$, at 45 .

${ }^{48}$ At 124 .

${ }^{49}$ At 125 .

50 Thornton, above n 46, at 4.
} 
The coming of the industrial revolution saw the public/private divide increasingly affect the way women's lives were lived and regulated, as the spheres of home/family and paid/unpaid work became more separate (both physically and conceptually). ${ }^{51}$ The symbiotic nature of the public/private divide continued, with the ability of men to fully enjoy the public sphere of paid work requiring the availability of another person, usually a woman, to undertake domestic labour. ${ }^{52}$ Over the last 100 years, as an increasing number of women have entered the workforce, the domestic labour required to ensure the smooth functioning of the public sphere of paid work has come to be provided by paid domestic workers.

2,500 years after Plato first relegated women and women's work to a private domain, the public/private divide now operates at a number of levels within both national and international law. At international law the public/private divide has been identified as the main obstacle standing in the way of the development and protection of women's rights. ${ }^{53}$ Feminist scholars have identified the gendered nature of the divide at the heart of the question of whether relationships between individuals, that is, relations in the private sphere, are subject to international human rights law. Traditionally only the public sphere of the relationship between individuals and the state has been the subject of human rights law. ${ }^{54}$ This would place the abuses suffered by domestic workers at the hands of their employers as the product of a relationship between private persons, and outside the purview of international human rights law.

Civil and political rights discourse has long been underpinned by the liberal ideology that the law is principally a means of regulating state intervention in private life, ${ }^{55}$ not actions within the private sphere between private actors. This approach has failed to acknowledge the crucial role the state plays in setting the notional boundaries between public and private life. The state is involved in the formation of families and how they function, ${ }^{56}$ it affects the distribution of power between individuals in the private sphere, ${ }^{57}$ and in many circumstances state intervention in private life is accepted and even encouraged (for example state reinforcement of parental authority). ${ }^{58}$

\footnotetext{
${ }^{51}$ Susan B Boyd "Can Law Challenge the Public/Private Divide? Women, Work and Family" (1996) 15 Windsor YB Access Just 161 at 163.

${ }^{52}$ Susan B Boyd, above n 51, at 161.

${ }^{53}$ Ivana Radičić "Human Rights of Women and the Public/Private Divide in International Human Rights Law" (2007) 3 CYELP 443 at 450.

${ }^{54}$ At 451.

${ }^{55}$ Donna Sullivan "The Public/Private Distinction in International Human Rights Law" in Julie Peters and Andrea Wolper (eds) Women's Rights, Human Rights: International Feminist Perspectives (Routledge, New York, 1995) 127.

${ }^{56}$ Olsen, above $\mathrm{n} 44$, at 837.

${ }^{57}$ Radičić, above n 53, at 453.

${ }^{58}$ Olsen, above n 44, at 837.
} 
Gradually it is becoming accepted that the myth of state non-intervention in the private sphere is just that, a myth, and there is now a strong basis on which it can be argued that acts within the private sphere are covered by at least some international human rights conventions. ${ }^{59}$ For example, in relation to violence against women the expert Committee responsible for the Convention to Eliminate All Forms of Discrimination Against Women said: ${ }^{60}$

Under general international law and specific human rights Covenants, States may also be responsible for private acts if they fail to act with due diligence to prevent violations of rights, or to investigate and punish acts of violence, and to provide compensation.

However the operation of international human rights norms in the private sphere continues to come up against those norms that call for the state to protect the institution of the family and its right to privacy. ${ }^{61}$ Even if it is accepted that international human rights law should protect people subject to abuse in the private sphere, the countervailing duty to protect family and privacy rights is so deeply ingrained that state non-intervention in domestic matters continues to be accepted. For domestic workers this means that their right to protection at international law may well be trumped by the family and privacy rights of their employer.

The influence of the public/private divide is found not just at international law, but at the level of the nation state, where the dividing line is often drawn between State regulation and private economic activity (the market), and between the market and the family. ${ }^{62}$ In the latter division the market (or workplace) is seen as the public sphere and it is contrasted with the private sphere of the family. This version of the public/private divide is arguably one of key reasons for the invisibility of domestic work, which has traditionally been performed by women as unpaid labour in the household and community. ${ }^{63}$ It has also contributed to the undervaluing of work perceived as 'women's work' in the marketplace. ${ }^{64}$

Perhaps most tellingly for domestic workers, the public/private divide is also used to distinguish between state regulation (the public) and family relations (the private). The private family is seen as an area beyond the reach of state regulation, as something that should be "protected from the public eye and from scrutiny by state and law". ${ }^{65}$ The right to a private family life has been framed as a right to be free from state interference in the family

\footnotetext{
${ }^{59}$ Andrew Clapham Human Rights in the Private Sphere (Clarendon Press, Oxford, 1996) at 94 - 104.

${ }^{60}$ Committee on the Elimination of Discrimination Against Women, General Recommendation 19, CEDAW/C/L.1/Add.15, 29 January 1992.

${ }^{61}$ See Universal Declaration of Human Rights GA Res 217A, III A/810 (1948), arts 12 and 16.

${ }^{62}$ Susan B Boyd (ed) Challenging the Public/Private Divide: Feminism, Law, and Public Policy (University of Toronto Press, Toronto, 1997) at 8 - 9.

${ }^{63}$ At 9.

${ }^{64}$ At 9 .

${ }^{65}$ At 9.
} 
sphere, ${ }^{66}$ effectively preventing the application of human rights standards in relationships deemed to be within that sphere. Domestic workers are often characterised as being 'part of the family', placing them beyond the reach of state regulation on the basis that the state should not interfere in family matters. Even if not seen as part of the family, the right of the domestic worker's employer to a private family life is likely to protect the actions of the employer from scrutiny.

This is the version of the divide that has been most soundly challenged, with particular focus given to domestic violence and child abuse as inherently private actions which should no longer support a policy of non-intervention simply on the basis that they occur between private individuals in the private sphere. ${ }^{67}$ The same argument may well be said to hold for domestic workers.

The importance of the public/private divide to domestic workers should not be underestimated. Domestic work occurs in the private home and often involves a relationship between two private persons. All versions of the public/private divide, in one way or another, place domestic work firmly in the legal shadows. This is clearly demonstrated by considering how the public/private divide operates in the world of work.

Under international law, the right to just and favourable conditions of work is protected by article 7 of the International Covenant on Economic, Social and Cultural Rights ("ICESCR"). ${ }^{68}$ However, the protection afforded by this article is confined to work in the public sphere, excluding the vast amount of economic activity engaged in by women around the world that takes place in the informal economy. ${ }^{69}$ This includes domestic work, which becomes invisible because it is considered to occur within the private, domestic sphere. Furthermore, article 7 guarantees women "conditions of work not inferior to those enjoyed by men, with equal pay for equal work", but the "international myopia with respect to the extent and economic value of women's work" $" 70$ continues to ensure that the gendered domestic workforce is undervalued.

At the domestic level, one way that the public/private divide influences the world of work is through anti-discrimination legislation, which generally protects persons in paid labour

\footnotetext{
${ }^{66}$ Radičić, above n 53, at 452.

${ }^{67}$ Olsen, above n 44.

${ }^{68}$ International Covenant on Economic, Social and Cultural Rights 993 UNTS 3 (opened for signature 16 December 1966, entered into force 3 January 1976).

${ }^{69}$ Hilary Charlesworth "What are "Women's International Human Rights"?" in Rebecca J Cook (ed) Human Rights of Women: National and International Perspectives (University of Pennsylvania Press, Philadelphia, 1994) 58 at 74.

${ }^{70}$ At 74 .
} 
originating in a contract of employment (the public). ${ }^{71}$ Just as with article 7 of the ICESCR, this means that many forms of domestic work will not receive the protection of antidiscrimination legislation because they do not occur within this liberal paradigm of the public sphere. ${ }^{72}$ Whether anti-discrimination provisions reach into the private sphere is an ongoing question at both the domestic and international levels. ${ }^{73}$ For instance, whilst most of the human rights committees have made clear statements on the obligation of states to eradicate discrimination against women by private individuals, ${ }^{74}$ it is common to find in domestic legislation exceptions pertaining to sex as a genuine occupational qualification, including in situations involving decency and physical intimacy. ${ }^{75}$

The functioning of the public/private divide in anti-discrimination legislation reveals why feminist scholars have been arguing for so long that the divide is a patriarchal creation with no sound ideological basis. Consider the essentially private nature of freedom of contract, and the right of employer and employee to bargain for whatever employment conditions they wish. Anti-discrimination provisions directly challenge the private nature of this relationship, and limit the autonomy of employers by proscribing limits on their ability to choose their employees freely. ${ }^{76}$ At the same time, the numerous exceptions to anti-discrimination provisions seek to retain the employer's autonomy, particularly in situations where the employer's privacy is at issue. Public and private become confused and overlap, and ultimately the notion of the private sphere is used merely to protect the autonomy of employers. One result of this is that work in the private sphere remains under-regulated and under-valued, and as this work continues to be dominated by women, the gendered aspect of the public/private divide is reinforced.

For domestic workers, the impact of the public/private divide means they continue to be part of an invisible workforce, relegated to a private sphere too often considered unworthy of the full recognition and protection of the law. It has been said that "[H]uman rights begin at home", 77 but for domestic workers the conception of the home as 'private' has meant that their rights have stopped at the front door. As a result domestic workers continue to suffer inequality and disadvantage, and it is for this reason that the International Labour Organisation moved in 2011 to regulate the terms and conditions of domestic work through an international hard law instrument. ${ }^{78}$

\footnotetext{
${ }^{71}$ Margaret Thornton “The Public/Private Dichotomy: Gendered and Discriminatory” (1991) 18 J L \& Soc'y 448 at 453.

72 At 453 .

${ }^{73}$ Radičić, above n 53, at 463.

74 Radičić, above n 53, at 463.

75 Thornton, above $\mathrm{n} 71$, at 454 .

${ }^{76}$ Thornton, above $\mathrm{n} 71$, at 454 .

${ }^{77}$ Marsha A Freeman "The Human Rights of Women in the Family: Issues and Recommendations for Implementation of the Women's Convention” in Peters and Wolper (eds), above n 55, at 149.

${ }^{78}$ Einat Albin and Virginia Mantouvalou "The ILO Convention on Domestic Workers: From the Shadows to the Light” (2012) 41(1) Ind Law J 67 at 70.
} 


\section{The International Labour Organisation Domestic Workers Convention}

The ILO's Convention No 189, concerning decent work for domestic workers, was adopted on 16 June 2011 by the ILO's International Labour Conference. The Convention came into force on 5 September 2013 and is binding on those countries that ratify it. The Convention and its associated Recommendation No 201 set new standards aimed at improving the working and living conditions of the world's domestic workers. Whilst the Convention lays down basic principles and measures regarding decent work for domestic workers, Recommendation No 201 is a non-binding instrument offering practical guidance for states on possible steps they may take to strengthen national law and policy on domestic work.

The Convention begins by defining domestic work and domestic worker. It will be remembered that domestic work means "work performed in or for a household or households", and domestic worker means "any person engaged in domestic work within an employment relationship" (Part II above). ${ }^{79}$ The Convention applies to all domestic workers, although limited exclusions are allowed for certain categories of domestic worker. ${ }^{80}$ The remaining provisions address issues of fundamental concern for domestic workers, which I will now briefly outline.

\section{A The promotion and protection of human rights ${ }^{81}$}

The Convention recognises that ensuring decent working and living conditions for domestic workers and the promotion and protection of their human rights are interrelated and mutually reinforcing objectives. As such, it requires Member states which ratify the Convention ("Members") to take measures to ensure the effective promotion and protection of human rights of domestic workers.

\section{B $\quad$ Fundamental principles and rights at work ${ }^{82}$}

Each Member is required to respect, promote and realise fundamental principles and rights at work in relation to domestic workers, namely:

(a) Freedom of association and the right to collective bargaining;

(b) Elimination of all forms of forced or compulsory labour;

(c) Effective abolition of child labour; and

(d) Elimination of discrimination in respect of employment and occupation.

\footnotetext{
${ }^{79}$ Article 1.

${ }^{80}$ Article 2 .

${ }^{81}$ Article 3(1).

${ }^{82}$ Article 3(2).
} 
The Convention emphasises the importance of protecting the right of domestic workers and their employers to establish and join organizations, federations and confederations of their choosing. ${ }^{83}$

The Convention also highlights the risks to children who are engaged in domestic work, and requires that Members set a minimum age for domestic workers of 18, consistent with the Minimum Age Convention No 138 and the Worst Forms of Child Labour Convention No $182 .^{84}$

C Protection from abuse, harassment and violence ${ }^{85}$

Article 5 of $\mathrm{C} 189$ recognises that domestic workers are particularly vulnerable to abuse, harassment and violence as a result of their workplace being shielded from public view and the tendency of domestic workers to work in isolation. To address this risk, C189 requires Members to take measures to ensure that domestic workers enjoy effective protection against all forms of physical, sexual and psychological abuse, harassment and violence.

\section{Fair terms of employment ${ }^{86}$}

Members are required to take measures to ensure that domestic workers enjoy fair terms of employment. This includes enjoying decent living conditions that respect their privacy if the worker is in a live-in situation.

\section{E Information on terms and conditions of employment ${ }^{87}$}

C189 requires Members to take measures to ensure domestic workers are informed of their terms and conditions of employment, and specifies the terms and conditions on which information must be provided. Additional protection is required for migrant workers, who must receive a job offer or written contract before crossing national borders.

\section{F $\quad$ Working time ti $^{88}$}

Members are required to take measures towards ensuring equal treatment between domestic workers and workers generally in relation to hours of work, overtime, rest periods, and paid annual leave, whilst recognizing that the special characteristics of domestic work need to be taken into account. Recommendation No 201 indicates that this means domestic workers should be entitled to suitable rest periods during the day, allowing for meals and breaks to be taken. $^{89}$

\footnotetext{
${ }^{83}$ Article 3(3).

${ }^{84}$ Article 4.

${ }^{85}$ Article 5.

${ }^{86}$ Article 6.

87 Article 7.

${ }^{88}$ Article 10

${ }^{89}$ International Labour Organisation Recommendation Concerning Decent Work for Domestic Workers Recommendation 201, para 10.
} 
Article 10 goes on to establish a weekly rest period of 24 consecutive hours, ${ }^{90}$ the effect of which is to require a fixed weekly day of rest which should be determined "by agreement of the parties". ${ }^{91}$ Compensatory rest is suggested when national laws, regulations or collective agreements allow for work to occur during periods of daily or weekly rest. ${ }^{92}$ Additionally, the extent to which stand-by hours are regarded as hours of work is left to the determination of the Member state. ${ }^{93}$

\section{G Remuneration ${ }^{94}$}

C189 recognises that low levels of remuneration are common in domestic work, and lays down principles with regard to minimum wage, non-discrimination and the protection of remuneration to address this concern.

Health and safety ${ }^{95}$

C189 requires that Members take effective measures to ensure the occupational health and safety of domestic workers, but it is flexible as to the particular measures that Members may take and allows measures to be put in place progressively.

I Social security ${ }^{96}$

Members are required to take appropriate measures to ensure that, in respect to social security protection, domestic workers enjoy conditions no less favourable that those that apply to workers in general.

\section{$J \quad$ Protection for particular groups of domestic workers ${ }^{97}$}

C189 includes specific provisions relating to child labourers, live-in domestic workers and migrant domestic workers.

\section{Child domestic workers}

C189 emphasises the need to eliminate child domestic labour as well as paying attention to the specific needs of child domestic workers. In particular, C189 requires Members to take measures to ensure that child domestic workers are not deprived of

\footnotetext{
${ }^{90}$ Article 10(2).

${ }^{91}$ International Labour Organisation Recommendation Concerning Decent Work for Domestic Workers Recommendation 201, para 11(2).

92 International Labour Organisation Recommendation Concerning Decent Work for Domestic Workers Recommendation 201, para 12.

${ }^{93}$ Article 10(3).

${ }^{94}$ Articles 11, 12 and 15.

95 Article 13.

${ }^{96}$ Article 14.

${ }^{97}$ Articles 4 (child labourers), 6 and 9 (live-in domestic workers), and 8 (migrant domestic workers).
} 
compulsory education, and that their work does not interfere with opportunities for further education or vocational training. ${ }^{98}$

\section{Live-in domestic workers}

Many domestic workers around the world live in the households for which they work. This is particularly true for migrant domestic workers. There are particular risks and issues associated with live-in arrangements which $\mathrm{C} 189$ addresses. Members are required to:

a. Ensure that live-in domestic workers are free to reach agreement with employers on whether or not they will reside in the household; $;^{99}$

b. Ensure that live-in domestic workers enjoy decent living conditions including respect for privacy; ${ }^{100}$

c. Ensure that live-in domestic workers do not have to remain in the household, or with members of the household, during periods of rest or leave; ${ }^{101}$ and

d. Ensure that live-in domestic workers have the right to keep their identity and travel documents in their possession. ${ }^{102}$

\section{Migrant domestic workers}

Because migrant domestic workers are particularly vulnerable, C189 includes provisions that specifically concern migrant workers and the needs and risks they face. Members are required to:

a. Cooperate with each other to ensure effective application of the Convention; ${ }^{103}$

b. Ensure that migrant workers receive an enforceable written contract or job offer that is enforceable in the country of employment, before travelling to that country; ${ }^{104}$ and

c. Take measures to specify the conditions under which domestic workers may be repatriated at the end of their employment. ${ }^{105}$

\section{K Private employment agencies ${ }^{106}$}

Members must take appropriate measures to protect domestic workers from abusive practices of private employment agencies.

\footnotetext{
${ }^{98}$ Article 4(2).

99 Article 9(a).

${ }^{100}$ Article 6.

${ }^{101}$ Article 9(b).

${ }^{102}$ Article 9(c).

${ }^{103}$ Article 8(3).

${ }^{104}$ Article 8(1).

${ }^{105}$ Article 8(4).

${ }^{106}$ Article 15.
} 


\section{Compliance and enforcement ${ }^{107}$}

C189 requires Members to:

i. ensure domestic workers have effective access to courts, tribunals or other dispute mechanisms;

ii. establish effective and accessible complaint mechanisms; and

iii. develop and implement measures for labour inspection, enforcement and penalties.

Labour inspection methods receive particular attention in this part of the Convention. Members must develop and implement labour inspection measures, ${ }^{108}$ and specify the conditions under which access to household premises may be granted, although due respect must be given to the privacy of the household. ${ }^{109}$

\section{Implementation}

Members are required to implement the provisions of C189 through laws and regulations, and in consultation with representative employers' and workers' organizations. Provision is also made for implementation through collective agreements, or by extending or adapting existing measures to cover domestic workers. ${ }^{110}$ Provisions under other international Labour Conventions that are more favourable to domestic workers are not affected by C189. ${ }^{111}$

Articles 20 to 26 concern ratification and entry into force of the Convention. Article 21 says that $\mathrm{C} 189$ will come into force twelve months after the date on which ratifications from two Members have been registered with the Director-General of the International Labour Office. The first two members to ratify C189 were Uruguay on 14 June 2012 and the Philippines on 5 September 2012. As a result, C189 came into force on 5 September 2013. Thereafter, C189 shall come into force for any Member twelve months after the state registers its ratification. On 20 September 2013 Germany became the tenth nation to ratify C189. ${ }^{112}$

The cumulative effect of the substantive articles of $\mathrm{C} 189$ is to send a strong message that domestic workers, like other workers, have the right to decent working and living conditions and to minimum protection under the law. The adoption of $\mathrm{C} 189$, only the eighth ILO Convention to be passed in the last 12 years, signals the importance that the ILO places on improving working conditions of domestic workers. ${ }^{113}$ It represents a shift in policy thinking

\footnotetext{
${ }^{107}$ Articles 16, 17 and 18.

108 Article 17(2).

109 Article 17(3).

${ }^{110}$ Article 18.

111 Article 19.

${ }^{112}$ The other countries to have ratified the Convention are Guyana, the Plurinational State of Bolivia, Italy, Mauritius, Nicaragua, Paraguay and South Africa. International Labour Organization "Ratifications of C189 Domestic Workers Convention, 2011 (No 189)" <www.ilo.org>.

${ }^{113}$ Albin and Mantouvalou, above n 78, at 70.
} 
at the international level on how the sector should best be regulated, based on the principle that "domestic workers are workers like other workers and therefore are equally entitled to respect of their rights and dignity". 114

The texts of C189 and Recommendation No 201 were arrived at through consensus, after a comprehensive preparatory process involving research into existing law and practice relating to domestic work, consultations and negotiations between ILO member states and their delegates. ${ }^{115}$ An overwhelming majority of delegates voted in favour of adopting C189, with the result of the vote being 396 in favour, 16 against and 63 abstentions. ${ }^{116}$

New Zealand voted in favour of adopting C189, although the path of the New Zealand delegates to that vote was not always clear-cut. In this Part, I will evaluate the contribution made by New Zealand delegates to the preparation and adoption of $\mathrm{C} 189$, before moving on to consider how New Zealand's domestic workers are currently protected by domestic legislation.

\section{$N \quad$ New Zealand and the Domestic Worker Convention}

New Zealand was a founding Member of the ILO and has sent a tripartite delegation of government, employer and worker delegates to the International Labour Conference every year since 1935. ${ }^{117}$ New Zealand also attends the Governing Body meetings held in Geneva in March and November each year and, as part of these forums, participates in international labour standard setting and supervisory processes, including those for C189.

In 2010, New Zealand's employer member Paul Mackay was appointed to be one of six members of C189's drafting committee by the Committee on Domestic Workers, ${ }^{118}$ and was subsequently appointed Vice-Chair of the Committee. ${ }^{119} \mathrm{Mr}$ Mackay's role on the Committee, combined with the active participation of New Zealand's government and worker delegates at International Labour Conference sessions, meant New Zealand took a full part in the preparation and adoption of $\mathrm{C} 189$.

In June 2010, when the International Labour Conference tested the waters on support for the adoption of a convention concerning domestic workers, New Zealand voted against the establishment of a convention - an action which reportedly drew gasps from other delegates

\footnotetext{
${ }^{114}$ International Labour Office, above n 2, at 6.

${ }^{115}$ International Labour Office, above n 2, at 6.

${ }^{116}$ International Labour Office Twenty-first sitting, Provisional Record No 30, International Labour Conference, 100th Session (2011) at 42.

${ }^{117}$ Ministry of Business, Innovation and Employment "International Services: Membership of the International Labour Organisation" Department of Labour $<$ www.dol.govt.nz $>$.

${ }^{118}$ International Labour Office Report of the Committee on Domestic Workers: Provisional Record No 12, International Labour Conference, 99th Session (2010) at [3].

${ }^{119}$ International Labour Office Report of the Committee on Domestic Workers: Provisional Record No 15, International Labour Conference, 100th Session (2011) at [2].
} 
as the vote was cast. ${ }^{120}$ There was also considerable unhappiness within New Zealand at this decision, with Marilyn Waring apologising to the women of the Commonwealth for New Zealand's vote. $^{121}$

The extent of the discontent was perhaps one reason why the government went on to change its position on adoption of a domestic worker's convention. The government delegate, explaining New Zealand's vote against C189 to the Committee on Domestic Workers, stated that the government had voted in favour of a Recommendation rather than a Convention on the basis that many existing Conventions were not being applied, and that adopting another Convention might not be the best "practical mechanism[s] to promote the rights of domestic workers". 122

Having explained away New Zealand's controversial vote, the government delegate then moved to clarify why New Zealand now supported the idea of a convention concerning domestic workers. The government delegate recognised the importance of decent work for domestic workers, acknowledging that domestic work often takes place behind closed doors, in poor conditions and with inadequate protection. ${ }^{123}$ He offered a positive view of New Zealand's approach to the proposed convention, saying that the government delegation intended to "participate actively in the Committee's discussion", ${ }^{124}$ and emphasised inter alia the need for "practical and effective means to resolve the key issues", to "promote observance by focussing on realistic measures", and to generate an outcome "that could be widely ratified or adopted by member States". 125

During the consultations that followed, the position of the New Zealand government and employers became clear. Although they supported the concept of decent work for domestic workers, they believed that international labour instruments "should be generally applicable rather than sector-specific". ${ }^{126}$ In my opinion this position is unsound. Generally applicable instruments are unable to address the particular challenges that workers face in a specific sector, which means that there is a risk that vulnerabilities faced by domestic workers resulting from the very nature of the sector will not be adequately dealt with by the instrument. In ILO terminology, a sector-specific approach to domestic work enables it to be viewed as 'work like no other', so that the specific sectoral disadvantages encountered by domestic workers can be suitably addressed.

\footnotetext{
${ }^{120}$ New Zealand Council of Trade Unions "Day of Shame for NZ International Reputation” (5 June 2010) $<$ www.union.org.nz>.

${ }^{121}$ Marilyn Waring "NZ failure to ratify ILO domestic workers convention "shameful"” (23 June 2010) Institute of Public Policy: An Institute of AUT University <www.ipp.aut.ac.nz>.

${ }^{122}$ International Labour Office, above n 119, at [110].

${ }^{123}$ International Labour Office, above n 119, at [48].

124 At [48].

125 At [48].

${ }^{126}$ International Labour Office Decent Work for Domestic Workers Report IV(2) (2010) at 8.
} 
A number of concerns were raised by New Zealand delegates in areas where they seemed to feel that the proposed convention was going too far, although their position seemed mainly to be that New Zealand law already offered sufficient protection to domestic workers. ${ }^{127}$

One matter raised by the New Zealand government delegate concerned C189's requirement that child domestic labour be abolished. In relation to children being employed to do 'domestic chores', the government delegate said that: ${ }^{128}$

Provided that working conditions are not exploitative, do not interfere with the education of children and do not raise any health and safety issues, this employment is not harmful, but socially desirable, as it prepares children for independence and greater responsibility.

The government delegate also observed that the proposed health and safety provisions of C189 would be counter to New Zealand law, as householders hiring people to work in their home do not have the same health and safety obligations as other employers. ${ }^{129}$

Difficulties were also raised with article 17 of the proposed convention, regarding labour inspection, with the government delegate noting that under New Zealand law all workers have the right to contact the labour inspectorate, but that a labour inspector cannot enter a workplace that is a private house without the agreement of the occupier or a court-ordered warrant. $^{130}$

On a number of matters the New Zealand government delegate made observations that could be considered somewhat disingenuous. For example he said that "pregnancy and disability are prohibited grounds of discrimination in New Zealand"131 even though, as we will see later, s 27(2) of the Human Rights Act 1993 protects discrimination against domestic workers on both of these grounds (below Part V). Similarly the government delegate said that freedom of association and collective bargaining rights apply to all employees, but neglected to mention that certain categories of domestic worker are not considered to be employees under the law in New Zealand. ${ }^{132}$

Despite these concerns, New Zealand's delegates went on to vote in favour of adoption of C189. As required by article 19 of the ILO Constitution, the government delegates presented

\footnotetext{
${ }^{127}$ At 20 .

128 At 76.

129 At 96.

${ }^{130}$ At 205

131 At 259 .

${ }^{132}$ At 215 .
} 
a report to the New Zealand House of Representatives on 23 May 2012, which included discussion of the adoption of $\mathrm{C} 189 .{ }^{133}$ The report noted that: ${ }^{134}$

The implications of ratification of the Convention concerning Decent Work for Domestic Workers will need to be considered against current law, policy and practice. New Zealand will continue to consider the possibility of ratification of this Convention.

As of 6 October 2013, no consideration of the implications of ratification of C189 has been made (or if it has, it has not been made public), and no further move has been made by the Government to ratify $\mathrm{C} 189$.

\section{The New Zealand Statutory Scheme}

In this Part, I will examine the coverage of domestic workers in New Zealand's domestic legislation, before considering the current law against the requirements of C189 in Part VI.

\section{A Employment Relations Act 2000}

The principal piece of legislation responsible for the protection of workers' rights in New Zealand is the Employment Relations Act 2000 ("ERA"). The ERA regulates minimum conditions of employment in New Zealand by promoting the notion of 'good faith' workplace relationships. ${ }^{135}$ It sets out some of the main obligations of employers and employees, including in relation to:

- Terms and conditions of employment (Part 6);

- Trial and probation periods (section 67);

- Freedom of association and collective bargaining (Parts 3 and 5);

- Union membership (Part 4);

- Flexible working (Part 6AA), breastfeeding (Part 6C), rests and meal breaks (Part 6D);

- Personal grievances, disputes and enforcement (Part 9); and

- Labour inspection (section 223).

The Employment Relations Act covers full-time, part-time and casual workers, but excludes volunteers who do not expect to be rewarded for work performed as a volunteer. ${ }^{136}$ An employee cannot be asked to agree to less than the minimum rights set out in the ERA and

\footnotetext{
${ }^{133}$ Office of the Clerk "Papers and petitions presented" (23 May 2012) Parliament New Zealand $<$ www.parliament.nz>.

${ }^{134}$ Report of the New Zealand Government Delegates on the One Hundredth Session of the International Labour Conference, Geneva, 1 June to 17 June 2011 (23 May 2012).

${ }^{135}$ Employment Relations Act 2000, s 4.

${ }^{136}$ Section 6(1)(c).
} 
associated legislation. ${ }^{137}$ Any worker covered by the Employment Relations Act is guaranteed minimum rights at work, which apply whether they are written into their employment agreement or not, ${ }^{138}$ whilst exclusion from the terms of the Act will leave a worker vulnerable to exploitation or abuse and with limited legal recourse against their employer.

Protection under the Employment Relations Act should be the most elementary level of protection for domestic workers, ensuring their minimum rights at work. However, there is no distinct category of domestic worker in the ERA, so to evaluate whether domestic workers are covered by the Act it is necessary to take each category of domestic worker as described in Part II above and assess whether their particular type of employment is caught by the Act.

The key concept at the heart of the Act is that of the employment relationship. The first stated object of the ERA is "to build productive employment relationships through the promotion of good faith in all aspects of the employment environment and of the employment relationship". ${ }^{139}$ Employment relationship is defined in section 4(2)(a) as including inter alia the relationship between "an employer and an employee employed by the employer". ${ }^{140}$ Whether a domestic worker is in an employment relationship therefore depends on whether they are an "employee".

The definition of employee is found in section 6 of the Act. The relevant part of definition says that employee: ${ }^{141}$

(a) means any person of any age employed by an employer to do any work for hire or reward under a contract of service.

A contract of service is a contract between an employer and an employee where the employee is reliant on the employer for the arrangement and management of their terms and conditions of employment. A contract of service is distinguishable from a contract for service by the nature of the person performing the work. Where the contract is one for service, the worker is an independent contractor. This means that they are likely to have greater autonomy than an employee in a contract of service; for instance, independent contractors arrange their own remuneration, holidays, and other benefits. ${ }^{142}$ Employees, who lack the degree of autonomy

\footnotetext{
137 "Your basic rights as an employee" Ministry of Business, Innovation and Employment <www.mbie.govt.nz>. Minimum rights at work are also provided by the Holidays Act 2003, Minimum Wage Act 1983, Equal Pay Act 1972, and Parental Leave and Employment Protection Act 1987.

138 Above, n 137.

139 Section 3.

${ }^{140}$ The remaining seven employment relationships described in section 4(2)(a) concern unions and employers engaged in collective bargaining, and can therefore be set aside for the purposes of the this discussion.

${ }^{141}$ Section 6(1).

${ }^{142}$ Mazengarb's Employment Law (online loose-leaf ed, Lexis Nexis) at [ERA6.5].
} 
of independent contractors, benefit from the protection of the Employment Relations Act. Independent contractors are excluded from the protection of the Act.

A domestic worker who is employed under a contract of service is therefore an employee for the purposes of the Employment Relations Act and will benefit from its general protection. This means that any domestic worker employed by a private employment agency (category 2 above) is clearly entitled to the same protection as any other type of worker, as they are an employee engaged in a contract of service with the employment agency.

Category 3 domestic workers (those employed by District Health Boards to look after people in their own home) could in some instances be considered as independent contractors and so fall outside the protection of the ERA. This possibility was canvassed by the Court of Appeal in 1996 in Cashman v Central Regional Health Authority. ${ }^{143}$ The Court recognised that workers who provided care for old and/or disabled people in their own home were "vulnerable and susceptible to manipulation", and that it was necessary to bring them within the protection of the Act. The Court achieved this by finding that such workers were "homeworkers" and, therefore, employees for the purposes of the Employment Contracts Act 1991.

When the Employment Relations Act 2000 replaced the Employment Contracts Act, it codified the decision in Cashman by specifically provided a definition of "homeworker" in section 5. "Homeworker": ${ }^{144}$

(a) means a person who is engaged, employed, or contracted by any other person (in the course of that other person's trade or business) to do work for that other person in a dwellinghouse (not being work on that dwellinghouse or fixtures, fittings, or furniture in it); and

(b) includes a person who is in substance so engaged, employed, or contracted even though the form of the contract between the parties is technically that of vendor and purchaser.

If a domestic worker falls within this definition then $\mathrm{s} / \mathrm{he}$ is considered to be an employee and will be covered by the provisions of the ERA. ${ }^{145}$ This means that a domestic worker who works in someone's home for a third party, for example, a cleaner employed by a District Health Board to provide support for elderly people in their home (a category 3 worker), will receive the same protection as category 2 domestic workers and all other employees.

\footnotetext{
${ }^{143}$ Cashman v Central Regional Heath Authority (1996) 3 ERNZ 159.

${ }^{144}$ Section 5.

145 Section 6.
} 
So far we have seen that domestic workers who work for a private employment agency, or those who work for any other third party ("homeworkers"), receive the protection of the minimum employment rights provided by the Employment Relations Act. What about category 1 and 4 workers - those who are direct employees of a homeowner working in the employer's home, and those who are self-employed contractors?

Self-employed contractors, such as a "Mr Green" franchise owner, are workers in an employment relationship where the contract is for service rather than of service; they are responsible for managing their own employment conditions and benefits. As discussed above, workers hired under a contract for service are not employees for the purposes of the ERA, ${ }^{146}$ and therefore do not receive its protection. This means that the worker is no longer ensured of the legal protection of such important rights as: the right to a written employment agreement; freedom of association and union membership; entitlement to breastfeeding, rest and meal breaks, and; personal grievance mechanisms, dispute and enforcement mechanisms.

The definition of employee established by section 5 of the ERA is also the definition used in the Holidays Act $2003^{147}$ and the Minimum Wage Act 1983. ${ }^{148}$ These Acts provide such key minimum employment entitlements as a right to four weeks' annual holidays, paid public holidays, and the right to be paid at least the minimum wage. Domestic workers who are selfemployed contractors, and so are not considered employees, do not benefit from these minimum entitlements, just as they do not benefit from protections provided by the ERA.

The same is also arguably the case for individual domestic workers who work on their own behalf, directly for the homeowner, in that person's home (category 1 workers). For example a student who cleans houses on a casual basis to supplement his or her student loan, a selfemployed nanny, or a mother who works part-time as a domestic worker on her own account, are all engaged in contracts for service. These workers will not benefit from protections included in the ERA, the Holidays Act and the Minimum Wage Act.

This conclusion is supported by the National Equal Opportunities Network, which says in its analysis of the human rights framework for aged-care that: "it is worth noting that the ERA does not cover people who are working for a homeowner in a direct contractual relationship". 149

\footnotetext{
146 Section 6(1).

${ }^{147}$ Holidays Act 2003, s 5.

${ }_{148}$ Minimum Wage Act 1983, s 2.

${ }^{149}$ National Equal Opportunities Network “Aged-care Inquiry: Human Rights Framework"

$<$ www.neon.org.nz>.
} 
The ERA does try to limit the employment relationships that classify as contracts for service by requiring that the court determine the real nature of the relationship between the parties. ${ }^{150}$ It is clear, however, that the ERA differentiates between domestic workers working in a private home who are employed by a third party and those in a direct contractual relationship with the homeowner. Domestic workers working for an employment agency in a contract of service receive the full benefit of the Act as employees - as do those working for a third party who fit the homeworker category. Those who are self-employed contractors and those who work directly for a homeowner, in that person's private home, receive no protection under the ERA.

There is one area of the ERA where even those domestic workers who are employees receive less protection than other employees, and that is in relation to access to the workplace. Section 19 states that, for the purposes of sections 20 to 25 of the ERA, a workplace does not include a dwellinghouse. For the purposes of the ERA, dwellinghouse: ${ }^{151}$

(a) means any building or any part of a building to the extent that it is occupied as a residence; and

(b) in relation to a homeworker who works in a building that is not wholly occupied as a residence, excludes any part of the building not occupied as a residence.

Sections 20 to 25 regulate the right of union organisers to enter the workplace, and the exclusion of dwellinghouse from the definition of workplace means that union organisers do not have the right to access domestic workers in their place of work. The right to freedom of association of domestic workers is therefore more limited than is the case for other employees under the ERA.

Similarly, labour inspectors do not have the same access to a workplace that is a private home as they do to any other workplace. ${ }^{152}$ For example, if an inspector wishes to enter a dwellinghouse s/he must have the consent of the occupier, or an entry warrant from the court. ${ }^{153}$ As a consequence, even those domestic workers who are covered by the ERA receive less protection in relation to labour inspection than other employees.

\section{B The Health and Safety in Employment Act 1992}

A similar pattern of excluding from legislative protection those domestic workers employed directly by homeowner/occupiers, and of limiting access to the workplace of domestic

\footnotetext{
${ }^{150}$ Section 6(2).

151 Section 5.

152 Sections 229 and 230.

153 Section 230.
} 
workers, is seen in another important piece of employment legislation, the Health and Safety in Employment Act 1992 ("the Health and Safety Act")

The Health and Safety Act requires employers to "take all practicable steps to ensure the safety of employees whilst at work". ${ }^{154}$ However, domestic workers employed by the occupier of a home to do "residential work" are excluded from the definition of employee. Residential work means: ${ }^{.155}$

domestic work done or to be done in the home; or work done or to be done in respect of the home, by a person employed or engaged by the occupier solely to do work of one or both of those kinds in relation to the home.

Domestic workers contracted directly by the occupier of a home to do work in the occupier's home will therefore not receive the protection of the Health and Safety Act. Reflecting the same pattern seen in the ERA, cleaners employed by a third party such as a District Health Board or private employment agency will be protected, differentiating domestic workers by their type of employment relationship. ${ }^{156}$

The Department of Labour however has stated that it is the nature of the workplace that draws the focus of the statute: ${ }^{157}$

Householders who hire people either as contractors or as employees - solely to work on or in their home - do not have any responsibilities under the Act. For example, if you employ a cleaner for your home, you do not have the duties of an employer under the Act (emphasis added).

During the preparatory stages of C189, New Zealand's government delegate said that the Health and Safety Act's exclusion of domestic workers contracted by a householder to work in their home was due to the "private nature of the workplace". ${ }^{158}$ He went on to explain that the Health and Safety Act exception is in fact dual in purpose, in that it applies neither to the home as a workplace nor to a person performing residential work.

It is therefore quite unclear precisely what the rationale is for excluding this subset of domestic workers from the protection of the Health and Safety Act. It could be either the nature of the workplace as a private home, or the nature of the employment relationship as one between two private parties. Both of these explanations fall into the realm of justification

\footnotetext{
${ }^{154}$ Health and Safety in Employment Act 1992, s 6.

155 Section 2(1).

${ }^{156}$ Williams, Tortell and Callister, above n 17, at 708.

${ }^{157}$ Department of Labour A Guide to the Health and Safety in Employment Act 1992 (July 2003) at [1.4].

${ }^{158}$ At 96.
} 
based on the public/private divide, a justification which I would argue is not sufficient to warrant putting the health and safety of domestic workers at risk.

For those domestic workers who are protected, it is unclear just how far the Health and Safety Act would go in requiring third party employers to "take all practicable steps" to ensure the safety of their employees, considering that the workplace of those employees is someone's private home. The very nature of the workplace limits the employer's control over it. What exactly is a District Health Board supposed to do to ensure that a private home is safe for an aged-care worker, for example? Where is the balance to be struck between an employer ensuring the health and safety of its employees, and the right of a homeowner/occupier to manage their home?

At least in relation to home health care, the Department of Labour advises employers that although they need to take into account the homeowner/occupiers "beliefs and right to make personal choices about how they manage their home setting", these beliefs and rights "should not be considered to override the employee's right to a safe place of work". ${ }^{159}$ This is a clear move away from the traditional public/private divide perspective that would uphold the rights of homeowner/occupiers to autonomy and privacy over the rights of domestic workers. If employers were to accept the Department of Labour's position, it is possible that an employer could refuse to send an employee into a home if they consider that it is not a safe place of work.

Whilst this is an encouraging development, the reality is that in order for an employer to make this assessment, there has to be some method available for workplace inspections. Unfortunately, health and safety inspectors have only limited ability inspect workplaces that are homes. In much the same way that labour inspectors are limited under the ERA, health and safety inspectors cannot enter a place of work that is a home, without the consent of the occupier or a court-ordered warrant. ${ }^{160}$ Without an established system of workplace inspection enabling employers to regularly assess the safety of home-based workplaces, I would argue that the Department of Labour's advice to employers, that they should place the health and safety of employees at least on a par with the rights of the homeowner, will remain an ideology rather than a practical reality.

The Department of Labour recognises that domestic work can be dangerous and, in particular, that domestic workers may be exposed to workplace hazards and violent or aggressive behaviour. ${ }^{161}$ However, despite the risk to domestic workers, those employed directly by a homeowner/occupier receive no protection under the Health and Safety Act, and

\footnotetext{
${ }^{159}$ Department of Labour Health and Safety Guidelines For Home-Based Health Care Services (May 2002 ) at 8.

${ }^{160}$ Health and Safety in Employment Act 1992, ss 31(2)(a) and 31(3)(a).

${ }^{161}$ Department of Labour, above n 159, at 8 and 39.
} 
those who are covered by the Act may receive only limited protection when the nature of the workplace, and the reach of labour inspectors, are taken into account.

\section{Domestic Workers in Other New Zealand Legislation}

A number of other pieces of New Zealand legislation contain provisions relevant to domestic workers. ${ }^{162}$ Some, such as the Income Tax Act 2007, refer explicitly to domestic workers. ${ }^{163}$ Others utilise the term "homeworker" established by the ERA, ${ }^{164}$ or refer to "residential work" as used in the Health and Safety Act. ${ }^{165}$ These pieces of legislation continue the pattern established in the ERA and the Health and Safety Act of treating different categories of domestic worker in disparate fashion. In particular, domestic workers who are employed to work in a private home directly by the homeowner/occupier receive less protection that those employed by a third party employer, "unconsciously carving the sector up for separate treatment". 166

This review of the legislative scheme for domestic workers in New Zealand so far reveals an incomplete pattern of protection, with both the type of employment relationship and the nature of the workplace being a private home leading to limitations in the protection afforded to domestic workers. The result is that two domestic workers performing the same tasks could find themselves treated very differently depending on the nature of their employment relationship, and could receive less protection than other employees because their workplace is a private home.

It is unclear from the legislation examined so far whether the motivation for these differences is to be found in the nature of the employment relationship or of the workplace. The answer to this question may lie in the Human Rights Act 1993, which deals explicitly with domestic employment in a private household.

\section{The Human Rights Act 1993}

Any person who applies for employment and/or is employed in New Zealand is prima facie protected against discrimination in that employment under section 22 of the Human Rights

\footnotetext{
${ }^{162}$ Accident Compensation Act 2001, Accident Compensation (Experience Rating) Regulations 2013, Accident Compensation (Work Account Levies) Regulations 2013, Accident Insurance (Insurer Returns) Regulations 1999, Charitable and Educations Trust Act 1946, Companies Act 1993, Health and Safety in Employment Regulations 1995, Health and Safety in Employment (Asbestos) Regulations 1998, Health and Safety in Employment (Pipelines) Regulations 1999, Health and Safety in Employment (Mining Underground) Regulations 1999, Income Tax Act 2007, Insolvency Act 2007, KiwiSaver Act 2006, Local Legislation Act 1939, Minimum Wage Act 1983, Protected Disclosures Act 2000, Tax Administration Act 1994, Waste Minimisation Act 2008, Wellington Methodist Charitable and Educations Trust Act 1946.

${ }^{163}$ Income Tax Act 2007, sub-pt MK, s MK 16, sub-pt RD, ss RD 16 and Y 1, schs 49 and 50.

${ }^{164}$ For example the Waste Minimisation Act 2008.

${ }^{165}$ For example the Health and Safety in Employment (Asbestos) Regulations 1998.

${ }^{166}$ Williams, Tortell and Callister, above n 17, at 714.
} 
Act 1993 ('the Human Rights Act'). There are 13 prohibited grounds of discrimination, ${ }^{167}$ but the Human Rights Act does allow for exceptions in some circumstances. ${ }^{168}$ Although a number of these exceptions could apply to domestic workers, ${ }^{169}$ one in particular deserves attention. Section 27(2) of the Human Rights Act says that:

Nothing in section 22 shall prevent different treatment based on sex, ${ }^{170}$ religious or ethical belief, disability, age, political opinion, or sexual orientation where the position is one of domestic employment in a private household.

This exception includes the largest number of grounds of discrimination of any exception related to employment in the Human Rights Act.

The Human Rights Commission confirms this situation in its guidelines for employers, when answering the question as to whether an employer can advertise specifically for a young person to be a nanny within a private home: ${ }^{171}$

Yes, where the job is one of domestic employment in a private household, the Act permits different treatment based on age, disability, political opinion, religious or ethical belief, sex or sexual orientation.

The title of section 27, which is a legitimate indicator of meaning according to section 5(3) of the Interpretation Act 1999, is "[E]xceptions in relation to authenticity and privacy". The conflation of "privacy" with "authenticity" in the title of the section is confusing. However, as only sub-section 27(1) contains the word "authenticity", I would argue that it is the only sub-section for which authenticity is the justification for the exception. ${ }^{172}$ Under the authenticity exception, discrimination on the ground of sex may be allowed in situations such as the acting of a particular part, or the modelling of gender specific clothing. ${ }^{173}$ It seems unlikely that authenticity could successfully be argued as a justifiable reason for

\footnotetext{
${ }^{167}$ Human Rights Act 1993, s 21.

${ }^{168}$ Sections 21(1) and $24-35$.

${ }^{169}$ For example, sections 27(3)(a) and (b). Section 27(3)(a) protects discrimination based on sex where a position needs to be held by one sex to preserve reasonable standards of privacy. Section 27(3)(b) protects discrimination based on sex where the nature or location of the employment makes it impracticable for the employee to live elsewhere than in premises provided by the employer, and-

(i) the only premises available (being premises in which more than 1 employee is required to sleep) are not equipped with separate sleeping accommodation for each sex; and

(ii) it is not reasonable to expect the employer to equip those premises with separate accommodation, or to provide separate premises, for each sex.

170 The ground 'sex' includes pregnancy and childbirth, section 21(1)(a).

${ }^{171}$ Human Rights Commission An A to Z for employers and employees: Pre-employment guidelines (July 2008) at 9.

${ }^{172}$ Human Rights Act 1993, s 27(1) protects discrimination based on sex or age where, for reasons of authenticity, being of a particular sex or age is a genuine occupational qualification for the position or employment.

${ }^{173}$ Tim McBride New Zealand Civil Rights Handbook: A guide to your civil rights under New Zealand law (Legal Information Services Inc, Auckland, 2001) at 7/23.
} 
discriminating against a domestic worker. Even though domestic workers have traditionally been women, domestic work does not require the worker to be of a particular sex.

This leaves privacy as the remaining justification for protecting discrimination against domestic workers under the Human Rights Act. It is not at all clear, however, how the right of an employer to privacy will be affected by the age of the domestic worker, or whether the domestic worker is pregnant, disabled, of a different political opinion or sexual orientation. A homophobic employer may well prefer not to hire a lesbian domestic worker for reasons of personal belief, but I would argue that a lesbian domestic worker is of no greater risk to the privacy of an employer than a heterosexual worker. Looking at it from another perspective, there may be practical reasons why a pregnant or disabled domestic worker would be unsuitable for some forms of domestic work (for example if heavy lifting is involved), but those reasons surely do not relate to the right to privacy of the employer. In fact the permitted grounds of discrimination seem to extend well beyond privacy and into social categorisation. ${ }^{174}$

The justification of the exception on the basis of privacy is even less clear if we consider the grounds on which discrimination against domestic workers is not permitted, namely: marital status, colour, race, ethnic or national origins, employment status or family status. It is hard to see the difference in the implications for an employers' privacy between for example race (not permitted), and ethical belief (permitted); or marital status (not permitted), and sexual orientation (permitted).

The selection of grounds on which discrimination against domestic workers is permitted is confusing. Understanding why the exception is framed the way it is - why some grounds are permitted and others are not - may lead to a better understanding of purpose of the exception. For this reason it is useful to look at this legislative history of the domestic worker exception.

The Human Rights Act 1993 replaced the Human Rights Commission Act 1977, which did include a domestic work exception but in a more limited form. Under section 13(3)(c) of the Human Rights Commission Act, discrimination in employment was not unlawful if it applied to "preferential treatment based on sex where the position is one of domestic employment in a private household". Presumably, this protection against a finding of unlawful discrimination was designed to protect employers who wished to preferentially hire, for example, women workers to be maids or male workers to be chauffeurs. Although highly gendered, this exception is based more on the right of employers to make autonomous employment decisions than about the private status of the workplace or the employer.

${ }^{174}$ Helen Fenwick Civil Liberties and Human Rights (3rd ed, Cavendish Publishing, London, 2002) at 1032. 
The ground of age was added to the exception as part of the Human Rights Commission Amendment Act 1992. ${ }^{175}$ The exception's remaining grounds of disability, political opinion, sexual orientation and religious or ethical belief were included when the Human Rights Act was adopted in $1993 .{ }^{176}$ Regrettably there is little explanation in the Parliamentary record as to why some of the Human Rights Act's new prohibited grounds of discrimination were added to the domestic work exception whilst others were not. ${ }^{177}$ This includes an absence of any consideration of the addition of the ground of religious or ethical belief, which had been available to Parliament to include in the exception since 1977 (on the basis that it was a prohibited ground of discrimination under the Human Rights Commission Act) but which until this point had not been part of the domestic work exception. There is also no reason provided as to why the grounds of employment and family status should not be added to the exception.

What little discussion did occur generally addressed the question of whether the exceptions included in the Bill needed to be there at all. For example the Hon John Robertson felt that the inclusion of exceptions in the Bill was hypocritical. He asked: ${ }^{178}$

Why should home owners who employ people in their homes be given exemptions from practising discrimination against age, sex, religious, ethical belief, disability, or political opinion, when the small business just down the road is deemed to be breaking the law by discriminating in such ways?

The legislative history of the domestic work exception throws no light on the purpose of the exception. Although justifying the exception on the basis of the right to privacy of the employer seems less than satisfying when one considers how the exception might be applied, the use of word "privacy" in the title of the section, and the phrase "private household" in both the domestic employment exception and in the Human Rights Commission guideline, provide the strongest guidance as to its purpose. They indicate that the exception was designed to protect the privacy of employer, or at least the private sphere of the household.

Perhaps the description of the workplace as a 'private' home resulted in the authors of the Human Rights Act assuming that the exception existed to protect the privacy of the employer within their home; hence being described as an exception in relation to privacy. Or perhaps the drafters simply felt that the sanctity of the private home deserved more protection than the rights of the worker, and little further consideration was given to the purpose of the exception.

\footnotetext{
${ }^{175}$ Human Rights Commission Amendment Act 1992, s 15A.

${ }^{176}$ Human Rights Act 1993, s 27(2).

${ }^{177}$ The Human Rights Act 1993 added the grounds of disability, political opinion, employment status, family status and sexual orientation to the prohibited grounds of discrimination in employment. Human Rights Act $1993, \mathrm{~s} 21$.

178 (27 July 1993) 537 NZPD 16922.
} 
As we saw earlier (above Part III), the idea that the private sphere should be beyond the reach of state regulation has long been an influence on human rights legislation. ${ }^{179}$ I would argue that the domestic work exception in the Human Rights Act effectively codifies the public/private divide, by placing domestic workers beyond the protection of the legislation, using a patchwork collection of grounds, on the basis that the work occurs in the private sphere and the employer is a private person.

During the introduction of the Human Rights Bill in 1992, the Hon Dr Michael Cullen questioned the need for clause 40(1), which protected different treatment based on age or gender where authenticity was at issue (for example the right to employ a man to play a male role in a play). The Hon D Graham replied that the clause had "been in the law a long time". ${ }^{180}$ Dr Cullen's response is worthy of statement in full: "Yes, it has been in the law for a long time, but that ... is not necessarily a good reason for it to remain within the law at the present time". ${ }^{181}$ I believe that the same could be said for clause 40(2) of the Bill, which became section 27(2) of the Human Rights Act - the domestic employment exception. That exception has been in the law a long time, but the time may have come to recognise that it serves no valid purpose and that it does not need to remain within the law in the 21 st century. At the very least, it is timely to review the exception to ensure that it is coherent in principle and application, and that it reflects the requirements of the latest relevant development in human rights law, the ILO's domestic worker Convention.

\section{Does New Zealand Law Meet the Requirements of Convention No 189?}

I have shown that the Employment Relations Act 2000, the Health and Safety in Employment Act 1992, and the Human Rights Act 1993 all afford incomplete protection to domestic workers. In this Part, I will compare the protection that domestic workers do receive under New Zealand's domestic legislation with the minimum protections afforded by C189.

Comparing New Zealand's domestic law and the minimum standards set out in C189, it is clear that there are several key areas where domestic workers in New Zealand may not receive the level of protection required by $\mathrm{C} 189$.

To begin with, based on the analysis conducted in Part $\mathrm{V}$ above, domestic workers who contract directly with a homeowner/occupier receive no protection under the ERA. This is a contravention of a number of articles of $\mathrm{C} 189$, including article 3(2), which requires that

\footnotetext{
${ }^{179}$ The New Zealand Civil Rights Handbook states that the Human Rights Act "is not intended to intrude into areas of private life", which is a textbook example of the operation of the public/private divide in human rights legislation. McBride, above n 173, at 7/10.

180 (15 Dec 1992) 532 NZPD 13213.

${ }^{181}$ Above, n 180.
} 
members respect, promote and realise the fundamental principles and rights at work of domestic workers.

The ILO's Declaration on Fundamental Principles and Rights at Work was adopted in 1998. It commits the ILO members States to respect and promote rights in four categories, whether or not they have ratified the relevant Conventions. The categories are: freedom of association and the effective recognition of the right to collective bargaining; the elimination of all forms of forced compulsory labour; the effective abolition of child labour; and the elimination of discrimination in respect of employment and occupation. ${ }^{182}$ Article 3(2) of the domestic worker Convention therefore echoes the obligations of ILO member States in the context of the 1998 Declaration, reinforcing the importance of these rights to domestic workers. By including the four categories of fundamental principles and rights at work in the same article as a more general call to protect "the human rights of all domestic workers", ${ }^{183} \mathrm{C} 189$ recognises that "the promotion and protection of human rights and ensuring decent working and living conditions for domestic workers are interrelated and mutually reinforcing objectives". ${ }^{184}$

To further emphasise the key value of the four categories of fundamental principles and rights at work, Recommendation No 201 makes specific suggestions as to actions that member States could take to ensure compliance with article 3(2). These include:

- Eliminating legislative or administrative obstacles to the right of domestic workers to establish or join organisations of their choosing; and ${ }^{185}$

- Strengthening the capacity of workers' and employers' organisations. ${ }^{186}$

Freedom of association and collective bargaining rights are therefore one aspect of the ERA which does not meet the requirements of $\mathrm{C} 189$, as domestic workers who are not employees for the purposes of the ERA are not guaranteed the right to freedom of association and collective bargaining. ${ }^{187}$ Additionally, the freedom of association and collective bargaining rights of domestic workers who are employees for the purposes of the ERA (for example those who work for third party employers such as a DHB) are at risk of being weakened by provisions of the Employment Relations Amendment Bill ("the Bill”) currently before Parliament. $^{188}$

\footnotetext{
182 International Labour Organisation Declaration on Fundamental Principles and Rights at Work 1998, art 2.

183 Article 3(1).

${ }^{184}$ International Labour Organization Decent work for domestic workers: C189 \& R201 at a glance (2011) at 12.

${ }^{185}$ International Labour Organization Recommendation Concerning Decent Work for Domestic Workers No 201, para 2(a).

${ }_{186}$ Para 2(b).

${ }^{187}$ Article 3(2)(a).

${ }^{188}$ Employment Relations Amendment Bill 2013 (105-1), cls 9 - 12.
} 
Under these provisions employers will no longer be required to conclude collective agreements and they will be able to opt out of multi-employer negotiations. The Bill also removes the requirement for employees to be covered by an extant collective agreement for the first 30 days of employment. ${ }^{189}$

Multi-employer collective agreements have been particularly beneficial to workers in the health sector in New Zealand (including employees who are domestic workers for the purposes of (189) and there is genuine concern that changes proposed by the Bill will further disadvantage an already vulnerable workforce. ${ }^{190}$ Rather than eliminating legislative obstacles to the full enjoyment of freedom of association and collective bargaining rights by domestic workers, the Bill seems likely to increase such obstacles. In my opinion, removing the requirement for 30 day collective agreement cover will also weaken the capacity of workers' organisations, rather than strengthen them.

The exclusion of domestic workers who are not employees from coverage under the ERA has other implications in relation to $\mathrm{C} 189$ as it cannot be certain that domestic workers will receive fair terms of employment and decent working conditions, ${ }^{191}$ or even that they will enjoy minimum wage coverage. ${ }^{192}$

In relation to remuneration, $\mathrm{C} 189$ requires not just that domestic workers enjoy minimum wage protection, but that remuneration is established without discrimination based on sex. ${ }^{193}$ This non-discrimination clause aims to address the gendered undervaluation and underpayment of domestic work. As confirmed by the Employment Court's recent decision in Service and Food Workers Union Ringa Tota Inc v TerraNova Homes and Care Limited ("TerraNova"), ${ }^{194}$ the undervaluation of gendered workforces is a very real issue in New Zealand. In TerraNova, the plaintiff union argued that employees of the defendant employer (an aged-care provider) were being paid at a lower rate of pay because the industry is dominated by women. ${ }^{195}$ Employees of the defendant were being paid between $\$ 13.75$ and $\$ 15.00$ per hour (the minimum wage being \$13.75). ${ }^{196}$ In this interim decision the Employment Court concluded that, when determining whether a rate paid to women in a sector dominated by women breached the Equal Pay Act 1972, it may be necessary to

\footnotetext{
${ }^{189}$ Clause 15.

${ }^{190}$ See New Zealand Public Service Association Submission to the Transport and Industrial Relations Select Committee by the Public Service Association: Te Pükenga Here Tikanga Mahi (25 July 2013) at 9 - 10.

${ }^{191}$ Article 6.

192 Article 11.

193 Article 11.

${ }^{194}$ Service and Food Workers Union Ringa Tota Inc v TerraNova Homes and Care Limited [2013] NZEmpC 157.

${ }^{195} 92$ per cent of the aged-caregiving workforce was reported as being women. Service and Food Workers Union Ringa Tota Inc v TerraNova Homes and Care Limited, above n 186, at [2].

${ }^{196}$ At [3].
} 
compare the pay-rates with those offered to workforces in unrelated sectors in order to find a gender-neutral comparator free from "systemic undervaluation of the work derived from current or historical or structural gender discrimination". 197

When the substantive case is heard it may be that the Court finds that pay-rates in the agedcare sector do breach the Equal Pay Act, leading to a requirement for employers in the sector to increase the wages of workers. At the moment however, it is arguable that at least one significant category of domestic workers in New Zealand is discriminated against on the basis of gender. This conclusion is strongly supported by the Human Rights Commission's 2012 report Caring Counts, which considered (amongst many things) the gendered nature of the pay parity issue in the aged-care workforce. One contributor to the report said: "the wages are a hangover from the old days - it's seen as women's work" and "the reason why the job is not valued is partly because it is done by women. They are treated like servants". ${ }^{198}$ The report concluded that low wages, pay inequality and pay inequity in home based aged-care is "an injustice grounded in historical undervaluation of the role", ${ }^{199}$ a finding that confirms both the ongoing influence of the public/private divide in policy making, and the precarious status of these domestic workers in New Zealand.

The possibility of gender discrimination in employment in relation to remuneration is only one example of a situation in which domestic workers in New Zealand do not receive the full benefit of the minimum standards of C189. Domestic workers may also find that in their employment they are discriminated against for reason of their sexual orientation, age or political opinion, but that this discrimination is protected by the Human Rights Act. C189 requires the elimination of all forms of discrimination against domestic workers in respect of employment, ${ }^{200}$ but as we have seen (above Part V), the Human Rights Act excludes domestic workers from protection against discrimination on the grounds of sex, age, religious or ethical belief, disability, political opinion and sexual orientation. New Zealand's antidiscrimination legislation therefore falls short of the standard set by C189 for the elimination of all forms of discrimination against domestic workers. It is also arguable that the lack of protection for domestic workers in this part of the Human Rights Act means that New Zealand is not taking measures to "ensure the effective promotion and protection of the human rights of all domestic workers", ${ }^{201}$ on the basis that freedom from discrimination is widely recognised as a fundamental human right. ${ }^{202}$

\footnotetext{
197 At [118].

${ }^{198}$ New Zealand Human Rights Commission Caring Counts Tautiaki Tika (May 2012) at 52.

${ }^{199}$ At 60.

${ }^{200}$ Article 3(2).

${ }^{201}$ Article 3(1).

${ }^{202}$ See for example Universal Declaration of Human Rights, article 7.
} 
Another unfavourable comparison between the provisions of C189 and New Zealand domestic law relates to occupational health and safety, as the Health and Safety Act expressly excludes domestic workers performing residential work from its protections (see above Part V). The limited powers of health and safety inspectors (along with labour inspectors under the ERA) also arguably contravene C189, by not appropriately striking a balance between the protection of domestic workers and the privacy of the household in which they work. ${ }^{203}$ In general, the exclusion of residential work from the Health and Safety Act and the difficulties associated with inspection mean that New Zealand cannot be said to have taken "effective measures ... to ensure the occupational safety and health of domestic workers" as required by article 13 of $\mathrm{C} 189$.

The rights of child and migrant domestic workers are not directly addressed in New Zealand law, and are certainly not given the explicit attention recommended by C189. For example, there is no minimum age of employment for children in New Zealand. ${ }^{204}$ The lack of a minimum age of employment is also not consistent with article 3 and with the ILO Convention No 138, the Minimum Age Convention. ${ }^{205}$

As C189 does not provide for reservations to be entered against the Convention, if New Zealand wished to ratify $\mathrm{C} 189$ then it would have to address all of these areas where its domestic law does not meet the minimum standards set by the Convention. For example it would have to include self-employed contractors and domestic workers who are employed directly by homeowner/occupiers in the definition of employee for the purposes of the Employment Relations Act 2000. Other changes would include setting a minimum age of employment for children and widening the scope of health and safety legislation to include domestic workers. These changes would likely prove difficult enough, but an even greater challenge exists to ratification of $\mathrm{C} 189$.

Some of the requirements of $\mathrm{C} 189$ are not met in respect to any category of worker in New Zealand law. For example under article 7(k), domestic workers are to be informed of any notice period in their employment agreement, but New Zealand law has no requirement that employment agreements contain a specific notice period. Similarly article 10(2) of C189 states that "weekly rest shall be at least 24 consecutive hours", but there is no mandatory 'day of rest' requirement in New Zealand law. It seems unlikely, to say the least, that the New Zealand government will introduce legislation that affects all working New Zealanders simply to meet its obligations under Convention No 189.

\footnotetext{
203 Article 17.

${ }^{204}$ Article 4(1).

${ }^{205}$ As a result, New Zealand has not ratified Convention No 138 (one of only 19 states not to have ratified this convention). International Labour Organization “C138 - Minimum Age Convention 1973 (No 138): Ratifications by Country” (4 October 2013) <www.ilo.org>.
} 


\section{The Case to Ratify Convention No 189}

\section{A Through the Lens of the Aged-Care Sector}

According to Statistics New Zealand, the New Zealand population aged 65 and over has doubled since the early 1980s to make up 14 per cent of the population, and is likely to double again by $2040 .^{206}$ This means that in 2040 more than 1 in 4 of the population will be aged over 65, with significant increases also predicted in the 85-plus age bracket. Many of these people will required care and support in their own homes.

In May 2012 the Human Rights Commission published a report into the aged-care sector in New Zealand. ${ }^{207}$ According to this report, by 2036 as many as 48,000 workers will be required to work in the aged-care sector - a trebling of the number currently employed. ${ }^{208} \mathrm{It}$ is ironic that the ageing of the population is also predicted to lead to a reduction in labour input, with the number of prime age workers declining from around $2025 .{ }^{209}$ This is of particular concern as the aged-care workforce itself is ageing, ${ }^{210}$ including those workers who provide care to people in their own homes. ${ }^{211}$ The combination of these demographic factors, along with increased pressure to provide aged-care within the home, ${ }^{212}$ is likely to lead to an extreme shortage of workers in the aged-care sector.

One solution to this looming problem that has been suggested by policy analyst Paul Callister, is to rely on migration to meet the future demand for domestic workers in the agedcare sector. ${ }^{213}$ Another solution, suggested in the Human Rights Commission report, is to make employment in the sector more attractive to under-represented or unemployed groups in the population. Currently the majority of aged-care workers who work in private homes are female, and many of them are migrant workers. ${ }^{214}$ The Human Rights Commission cites the preamble of ILO Convention No 189 to emphasise that marginalisation and lack of protection in relation to migrant workers, and systemic undervaluation and low pay which is characteristic of carers' roles carried out by women, are both prevalent in the aged-care sector. $^{215}$

The issues present in the aged-care sector provide an excellent argument for ratification of C189. The sector is facing a significant workforce deficit at the same time as an unprecedented rise in demand for home-based carers. Its workforce is populated by migrant

\footnotetext{
${ }^{206}$ Statistics New Zealand "Population aged 65-plus doubles since early 1980s" (press release, 14 August 2013).

${ }^{207}$ Human Rights Commission, above n 198.

208 At 23.

${ }^{209}$ Organisation for Economic Cooperation and Development Economic Surveys: New Zealand (June 2013).at 56.

${ }^{210}$ Human Rights Commission, above n 198, at 25.

${ }^{211}$ At 26.

212 At 28 .

213 Callister, Badkar and Williams, above n 29.

214 At 157.

${ }^{215}$ At 157.
} 
employees and women who suffer some of the poorest working conditions in the country. Even though these workers, employed as they are by a third party to work in someone's private home, receive the full protection of the Employment Relations Act, their working conditions are not improving and they remain vulnerable to an uncontrolled health and safety environment and the risk of discrimination in employment without legal recourse.

If the aged-care sector is to build its workforce it needs to improve the conditions of employment that its workers face. One way to achieve this would be for New Zealand to ratify Convention No 189 and bring its domestic law into conformity with the minimum standards of the Convention. As home-based care workers are included in the definition of domestic workers in $\mathrm{C} 189$, they would be guaranteed the minimum rights at work set out by the Convention.

It is also likely that some of the demand for new workers will have to be met from migration. Migrant workers are some of the most vulnerable of all domestic workers, ${ }^{216}$ and the protection of the provisions in $\mathrm{C} 189$ that relate to migrant workers could be crucial in terms of recruiting and retaining workers to this sector. In particular it would be beneficial to ensure written job offers and contracts of employment for migrant workers when they are recruited, to help migrant domestic workers understand their terms and conditions of employment and the protections they receive under the relevant legislation, to provide outreach services and access to complaint mechanisms, and to encourage cooperation between the New Zealand government and potential sending countries.

Taking just this one sector of the domestic work industry, it is possible to see the good that ratifying C189 could do. Ratification could improve the working lives of thousands of domestic workers in New Zealand whilst at the same time helping secure the future of a workforce that is of increasing economic and social importance to the country. On this basis alone, I would argue that New Zealand should ratify C189.

The balance that must be struck between protecting the employment and human rights of domestic workers and the right of homeowner/occupiers to privacy and autonomy becomes more strongly weighted in favour of the worker when consideration is given not just to the improvement that ratifying $\mathrm{C} 189$ would bring to the working conditions of domestic workers, but also to the economic and policy needs of New Zealand as it faces its ageing future.

Bearing in mind however that ratification on C189 is unlikely due to the considerable implications it would have in terms of amending New Zealand's domestic legislation, it is

\footnotetext{
${ }^{216}$ Committee on the Protection of the Rights of all Migrant Workers and Members of Their Families General comment No 1 on migrant domestic workers CMW/C/GC/ (2011).
} 
worth briefly considering other options available that could improve the outlook for domestic workers in New Zealand.

\section{B Other Options}

If the New Zealand government does not intend to ratify $\mathrm{C} 189$, but remains committed to finding "practical and effective means" 217 to address the plight of domestic workers, it has many alternative options available to it.

Relatively straightforward steps that could be taken include: encouraging the organization of domestic workers; raising awareness of the rights that domestic workers do have under New Zealand law; reaching out to the migrant worker population to ensure migrant domestic workers understand their fundamental rights and obligations at work in New Zealand; building an appreciation amongst employers of domestic workers that they have rights and obligations in relation to their domestic workers; and gathering sector-specific data to build the knowledge base on domestic work. All of these suggestions together amount to an education campaign on a nationwide scale that would raise awareness and understanding of domestic work in all its forms.

One of the most important actions that could be taken is the promotion of domestic worker organizations. Traditionally domestic workers have been viewed as "un-organisable", due mainly to the fact that they normally work in isolation in individual households, hidden from the view of traditional workers' organisations. ${ }^{218}$ In some countries domestic workers have been denied the right to organise, compounding the problem of worker isolation. ${ }^{219}$ Even in countries where they do have the right to organise, because they work in isolation it is difficult for them to do so. ${ }^{220}$ However, increasingly, domestic workers around the world are organizing themselves into unions or other forms of member-based organization. ${ }^{221}$ When domestic workers are organised they have a voice with which to make themselves heard and are then able to argue for their rights.

Unfortunately union membership is New Zealand is generally very low, at around 17 per cent of the total employed labour force. ${ }^{222}$ Proposed changes to the Employment Relations Act that will affect collective bargaining are not likely to improve rates of membership. ${ }^{223}$ Strong

\footnotetext{
${ }^{217}$ International Labour Office, above n 119, at [48].

${ }^{218}$ Hina Shah and Marci Seville "Domestic Worker Organizing: Building a Contemporary Movement for Dignity and Power” (2012) 75 Albany L Rev 413 at 418.

${ }^{219}$ International Labour Office, above n 7, at 83.

${ }^{220}$ At 84.

221 "Domestic Workers" Women in Informal Employment: Globalizing and Organizing <www.wiego.org>.

${ }^{222}$ Ministry of Business, Innovation and Employment "Union membership return report 2011" Department of Labour $<$ www.dol.govt.nz $>$.

${ }^{223}$ Employment Relations Amendment Bill 2013 (105-1) (explanatory note) at 2.
} 
representation by the unions, and support from Parliament, will therefore be required if domestic workers are to be encouraged to organise.

A very different route to protection of the rights of domestic workers may be possible through stronger application of New Zealand's Framework for Integrating Labour Issues into Free Trade Agreements. This framework was adopted in 2001 and it acts as a tool for guiding New Zealand's free trade negotiations with other countries. One element of the framework involves using the ILO's Fundamental Principles and Rights at Work as a basis for the discussion of labour standards during free trade negations. ${ }^{224}$ The Ministry of Foreign Affairs and Trade says of this element that: ${ }^{225}$

[A]s a minimum, the outcomes of all trade agreements to which New Zealand is a party must be generally consistent with and not undermine these core principles, the promotion of decent work, and the promotion and protection of universal human rights standards.

In future years, New Zealand's free trade partners who also supply domestic workers to New Zealand could potentially bring pressure to bear on the New Zealand government to ensure that the law as it applies to domestic workers meets the standard proscribed by this framework. The possibility of this happening will only increase as New Zealand's demand for domestic workers grows. Just as the major sending and receiving countries are currently entering into bilateral arrangements that protect their domestic workers, ${ }^{226}$ New Zealand's international relations could provide a future avenue for the protection of its domestic workers.

Whatever path it chooses to take, the New Zealand government has an obligation to report back to the ILO, at the request of the Governing Body, on its application of Conventions that it has not ratified. ${ }^{227}$ This obligation, along with mounting international awareness of the economic and social importance of domestic workers, is likely to ensure that domestic workers remain on the agenda of the New Zealand government for years to come.

\section{Conclusion}

Domestic workers are some of the most vulnerable of the world's workers. They are often invisible as a result of their unique place of work, undervalued because of the nature of their work, and under-protected by domestic legislation. In order to address the dis-advantageous position domestic workers so often find themselves in, the ILO adopted a new set of

\footnotetext{
${ }^{224}$ New Zealand Ministry of Foreign Affairs and Trade "Framework for Integrating Labour Issues into Free Trade Agreements" <www.mfat.govt.nz>.

${ }^{225}$ New Zealand Ministry of Foreign Affairs and Trade, above $\mathrm{n} 224$.

${ }^{226}$ For example see Philippines Department of Foreign Affairs "Philippines, Saudi Arabia agree on final text of bilateral Agreement on Domestic Worker Recruitment” (press release, 19 March 2013).

${ }^{227}$ Constitution of the International Labour Organisation, article 19.
} 
international labour standards concerning decent work for domestic workers. Convention No 189 sets minimum standards that recognise the value of domestic work whilst requiring member States to address existing exclusions of domestic workers from legislative protection.

Although some domestic workers in New Zealand do receive protection under employment legislation, there are significant areas where the protections afforded to domestic workers do not meet the minimum standards set by the ILO's domestic worker Convention No 189. Crucially, domestic workers who are employed directly by a homeowner/occupier receive no protection under the Employment Relations Act and domestic workers performing residential work are also excluded from the Health and Safety Act. Additionally, discrimination against domestic workers on the grounds of sex, age, disability, political option, religious or ethical belief and sexual orientation is protected under the Human Rights Act.

For many domestic workers in New Zealand, including those working in the aged-care sector, low pay and poor working conditions are a reality. If New Zealand's domestic workers are truly to be seen as workers like any other workers, to receive the same protection as any other New Zealand employee and those domestic workers in nations that have ratified Convention No 189, then ratification of the Convention and associated domestic legislative change may be necessary to bring domestic law into line with international labour law.

Whilst ratification of $\mathrm{C} 189$ remains unlikely, there are other avenues that could be pursued to improve the working lives of New Zealand's domestic workers. Whatever route the government of New Zealand chooses to take, growing international and domestic pressure and the exigencies of demographic change mean that the rights of domestic workers cannot remain in the shadows for much longer. ${ }^{228}$

${ }^{228}$ Albin and Mantouvalou, above $\mathrm{n} 78$. 


\section{Bibliography}

A Cases

$1 \quad$ New Zealand

Cashman v Central Regional Heath Authority (1996) 3 ERNZ 159.

Idea Services Ltd v Dickson EmpC Wellington WRC 31/08 and 34/08, 8 July 2009.

Service and Food Workers Union Nga Ringa Tota Inc v TerraNova Homes and Care Limited [2013] NZEmpC 157.

\section{B Legislation}

$1 \quad$ New Zealand

Accident Compensation Act 2001.

Accident Compensation (Experience Rating) Regulations 2013.

Accident Compensation (Work Account Levies) Regulations 2013.

Accident Insurance (Insurer Returns) Regulations 1999.

Charitable and Educations Trust Act 1946.

Companies Act 1993.

Education Act 1989.

Employment Contracts Act 1991.

Employment Relations Act 2000.

Employment Relations Amendment Bill 2013 (105-1),

Equal Pay Act 1972.

Health and Safety in Employment Act 1992.

Health and Safety in Employment Regulations 1995.

Health and Safety in Employment (Asbestos) Regulations 1998.

Health and Safety in Employment (Pipelines) Regulations 1999,

Health and Safety in Employment (Mining Underground) Regulations 1999,

Holidays Act 2003.

Human Rights Commission Amendment Act 1992.

Human Rights Commission Act 1977. 
Human Rights Act 1993.

Income Tax Act 2007.

Immigration Act 2009.

Insolvency Act 2007.

Interpretation Act 1999.

KiwiSaver Act 2006.

Local Legislation Act 1939

Minimum Wage Act 1983.

Protected Disclosures Act 2000.

Race Relations Act 1971.

Tax Administration Act 1994.

Waste Minimisation Act 2008.

Wellington Methodist Charitable and Educations Trust Act 1946.

\section{$2 \quad$ United Kingdom}

Race Relations Act 1976 (UK).

\section{Treaties and Conventions}

International Covenant on Economic, Social and Cultural Rights 993 UNTS 3 (opened for signature 16 December 1966, entered into force 3 January 1976).

International Labour Organisation Convention Concerning Decent Work for Domestic Workers Convention No 189 (opened for signature 16 June 2011, entered into force 5 September 2013).

International Labour Organisation Declaration on Fundamental Principles and Rights at Work 1998.

International Labour Organisation Minimum Age Convention No 138 (opened for signature 26 June 1973, entered into force 19 June 1976).

International Labour Organisation Recommendation Concerning Decent Work for Domestic Workers Recommendation 201.

International Labour Organisation Worst Forms of Child Labour Convention No 182 (opened for signature 17 June 1999, entered into force 19 November 2000).

Universal Declaration of Human Rights GA Res 217A, III A/810 (1948). 
D Books and Chapters in Books

Einat Albin "From 'Domestic Servant' to 'Domestic Worker"' in Judy Fudge, Shae McCrystal and Kamala Sankaran (eds) Challenging the Legal Boundaries of Work Regulation (Hart Publishing, Oxford, 2012).

Mimi Abramovitz Regulating the Lives of Women: Social Welfare Policy from Colonial Times to the Present (South End Press, Boston, 1988).

Marjorie Agosín (ed) Women, Gender, and Human Rights: A Global Perspective (Rutgers University Press, New Brunswick, 2001).

Philip Alston (ed) Labour Rights as Human Rights (Oxford University Press, Oxford, 2005).

Margaret Bedggood and Kris Gledhill (eds) Law into Action: Economic, Social and Cultural Rights in Aotearoa New Zealand (Thomson Reuters, Wellington, 2011).

Eileen Boris and Rhacel Salazar Parrenas (eds) Intimate Labours: Cultures, Technologies and the Politics of Care (Stanford University Press, Stanford, 2010).

Susan B Boyd (ed) Challenging the Public/Private Divide: Feminism, Law, and Public Policy (University of Toronto Press, Toronto, 1997).

Petra Butler and Andrew Butler The New Zealand Bill of Rights Act 1990: a commentary (LexisNexis Butterworths, Wellington, 2006).

Andrew Clapham Human Rights in the Private Sphere (Clarendon Press, Oxford, 1996).

Rebecca J Cook (ed) Human Rights of Women: National and International Perspectives (University of Pennsylvania Press, Philadelphia, 1994).

John DR Craig and S Michael Lynk Globalization and the Future of Labour Law (Cambridge University Press, Cambridge, 2006).

Eugenia Date-Bah (ed) Promoting Gender Equality at Work: Turning Vision into Reality (Zed Books Ltd, London, 1997).

Guy Davidov and Brian Langille (eds) The Idea of Labour Law (Oxford University Press, Oxford, 2011).

Robert L Dipboye and Adrienne Colella (eds) Discrimination at Work: The Psychological and Organizational Bases (Lawrence Erlbaum Associates Inc, Mahwah, 2005).

PJ Downey Human Rights and New Zealand (Human Rights Commission, Wellington, 1983).

Jean Bethke Elshtain Public Man, Private Woman: Women in Social and Political Thought (Martin Robertson, Oxford, 1981). 
Richard A Epstein Human Rights and Anti-discrimination Legislation (New Zealand Business Round Table, Wellington, 1996).

Ben Fine Women's Employment and the Capitalist Family (Routledge, London, 1992).

Helen Fenwick Civil Liberties and Human Rights (3rd ed, Cavendish Publishing, London, 2002).

Norma Y Glazer Women's Paid and Unpaid Labour: The Work Transfer in Health Care and Retailing (Temple University Press, Philadelphia, 1993).

Judith Glover and Gill Kirtan Women, Employment and Organizations (Routledge, Oxfordshire, 2006).

Bob Hepple and Erika M Szyszczak (eds) Discrimination: The Limits of Law (Mansell Publishing Ltd, London, 1992).

Grant Huscroft and Paul Rishworth (eds) Rights and Freedoms: The New Zealand Bill of Rights Act 1990 and The Human Rights Act 1993 (Brooker's Ltd, Wellington, 1995).

Martha Fetherolf Lautfi (ed) Women, Gender and Work: What is Equality and How Do We Get There? (International Labour Office, Geneva, 2001).

Catharine A MacKinnon Are Women Human? And Other International Dialogues (The Belknap Press, Cambridge, 2006).

Tim McBride New Zealand Civil Rights Handbook: A guide to your civil rights under New Zealand law (Legal Information Services Inc, Auckland, 2001).

Janet Henshall Monsen (ed) Women, Gender, Migration and Domestic Service (Routledge, London, 1999).

Julie Peters and Andrea Wolper (eds) Women's Rights, Human Rights: International Feminist Perspectives (Routledge, New York, 1995).

Shahra Razavi, Ruth Pearson and Caroline Danlay (eds) Globalization, Export-Oriented Employment and Social Policy: Gendered Connections (Palgrave MacMillan, Hampshire, 2004).

Paul Rishworth and others The New Zealand Bill of Rights Act (Oxford University Press, Melbourne, 2003).

Vinita Singh Women Domestics: Workers Within Households (Rawat Publications, Jaipur, 2007).

Pamela Sharpe (ed) Women, Gender and Labour Migration: Historical and Global Perspectives (Routledge, Oxfordshire, 2001).

Ann Stewart Gender, Law and Justice in a Global Market (Cambridge University Press, Cambridge, 2011). 
Margaret Thornton (ed) Public and Private: Feminist Legal Debates (Oxford University Press, Melbourne, 1995).

Marilyn Waring Counting for Nothing: What Men Value and What Women Are Worth (Allen \& Unwin, Wellington, 1988).

E Journal Articles

Einat Albin and Virginia Mantouvalou "The ILO Convention on Domestic Workers: From the Shadows to the Light" (2012) 41(1) Ind Law J 67.

Natasha Lycia Ora Bannan "Domestic Workers and their Right to be Heard: Residential Picketing Makes Visible the Invisible" (2011) 4 Crit 112.

Susan B Boyd "Can Law Challenge the Public/Private Divide? Women, Work and Family" (1996) 15 Windsor YB Access Just 161.

Paul Callister, Juthika Badkar and Jessie Williams Paid Caregivers and Domestic Workers: Some Policy Issues in Relation to Meeting Future Demand in New Zealand (2009) 5 Pol'y Quarterly 38.

Hilary Charlesworth "Feminist Methods in International Law" (2004) 36 Stud Transnatl L Poly 166

Hilary Charlesworth, Christine Chinking and Shelley Wright "Feminist Approaches to International Law" (1991) 85 Am J Intl L 613.

Martha Alta Chen "Recognising Domestic Workers, Regulating Domestic Work: Conceptual, Measurement, and Regulatory Challenges" (2011) 23 Can J Women \& L 167.

Karen Engle "After the Collapse of the Public/Private Distinction: Strategizing Women's Rights” (1993) 25 Stud Transnat'l Legal Pol'y 143.

Sheree J Gibb, David M Fergusson and Joseph M Boden "Gender Differences in Paid and Unpaid Work: findings from a New Zealand birth cohort” (2013) 9 Pol’y Quarterly 65.

Talle D Gilmore “The New York Domestic Workers' Bill of Rights: Justice at the Door" (2012) 7 Intercultural Hum Rts L Rev 147.

Hein de Haas "International Migration, Remittances and Development: myths and facts" (2005) 26 Third World Quarterly 1269.

Laurence R Helfer "Monitoring Compliance with Unratified Treaties: The ILO Experience" (2008) 71 Law \& Contemp Probs 193.

Robert A Kraft and Kathryn M Kraft "Legal Pitfalls When Hiring Domestic Help” (2011) 28 GPSolo 29.

Glenda Labadie-Jackson "Reflections on Domestic Work and the Feminization of Migration" (2008 - 2009) 31 Campbell L Rev 67. 
Virginia Mantouvalou "Servitude and Forced Labour in the 21st Century: Human Rights of Domestic Workers” (2006) 35(4) Ind Law J 395.

Virginia Mantouvalou “Are Labour Rights Human Rights?” (2012) 2 ELIJ 151.

Virginia Mantouvalou "Human Rights for Precarious Workers: The Legislative

Precariousness of Domestic Labour” (2012 - 2013) 34 Comp Lab L \& Pol’y J 133.

Terri Nilliasca “Some Women's Work: Domestic Work, Class, Race, Heteropatriarchy, and the Limits of Legal Reform" (2011) 16 Mich J Race \& L 377.

Frances E Olsen "The Myth of State Intervention in the Family" (1984 - 1985) 18 U Mich J L Reform 835.

Roza Pati "Domestic Servitude: A Contemporary Form of Slavery" (2012) 7 Intercultural Hum Rts L Rev 9.

Ivana Radičić "Human Rights of Women and the Public/Private Divide in International Human Rights Law" (2007) 3 CYELP 443.

Celina Romany "Women as Aliens: A Feminist Critique of the Public/Private Distinction in International Human Rights Law” (1993) 6 Harv Hum Rts J 87.

Andreas Schloenhardt and Jarrod Jolly "Honeymoon from Hell: Trafficking and Domestic Servitude in Australia” (2010) 32 Sydney L Rev 671.

Hina Shah and Marci Seville "Domestic Worker Organizing: Building a Contemporary Movement for Dignity and Power” (2012) 75 Albany L Rev 413.

Peggie R Smith "The Pitfalls of Home: Protecting the Health and Safety of Paid Domestic Workers" (2011) 23 Can J Women \& L 309.

Dorothy Q Thomas and Michele E Beasley "Domestic Violence as a Human Rights Issue" (1993) 15 Human Rights Quarterly 36.

Margaret Thornton "The Public/Private Dichotomy: Gendered and Discriminatory" (1991) 18 J L \& Soc'y 448 at 453.

Jessie Williams, Lisa Tortell and Paul Callister "The Mysterious Case of the Housemaid: Domestic Workers in New Zealand Law" (2009) NZ L Rev 695.

Michael J Wishnie "Immigrant Workers and the Domestic Enforcement of International Labor Rights" (2002) 4 U Pa J of Labour \& Emp L 529

F $\quad$ Parliamentary and Government Materials

(7 July 1977) 411 NZDP 1245.

(15 Dec 1992) 532 NZPD 13213. 
(27 July 1993) 537 NZPD 16922.

Michael Hobby International Labour Organisation, Report of the New Zealand Government Delegates on the One Hundredth Session of the International Labour Conference, Geneva, 1 June to 17 June 2011 (23 May 2012).

G Reports

Juthika Badkar The Future Demand for Paid Caregivers in a Rapidly Ageing Society (Department of Labour, Wellington, 2009).

Juthika Badkar, Paul Callister and Robert Didham Ageing New Zealand: The Growing Reliance on Migrant Caregivers (Institute of Policy Studies, Working Paper 09/08, July 2009).

Paul Callister The Changing Gender Distribution of Paid and Unpaid Work in New Zealand (New Zealand Treasury Working Paper 05/07, June 2005).

Paul Callister, Lisa Tortell and Jessie Williams Paid Domestic Work: A Private Matter or a Public Policy Issue? (Institute of Policy Studies Working Paper 09/02, March 2009).

International Labour Office Decent Work for Domestic Workers Report IV(1) (2010).

International Labour Office Decent Work for Domestic Workers Report IV(2) (2010).

International Labour Office Coverage of Domestic Workers by Key Working Conditions Laws (Domestic Work Policy Brief 5, 2011).

International Labour Office Domestic Workers Across the World: Global and Regional Statistics and the Extent of Legal Protection (2013).

International Labour Office Domestic Workers Count: Global Data on an Often Invisible Sector (2011).

International Labour Office Effective Protection for Domestic Workers: A Guide to Designing Labour Laws (2011).

International Labour Office Measuring the Economic and Social Value of Domestic Work (2011).

International Labour Office Report of the Committee on Domestic Workers: Provisional Record No 12, International Labour Conference, 99th Session (2010).

International Labour Office Report of the Committee on Domestic Workers: Provisional Record No 15, International Labour Conference, 100th Session (2011).

International Labour Office Twenty-first sitting, Provisional Record No 30, International Labour Conference, 100th Session (2011). 
Ministry of Business, Innovation and Employment Quarterly Labour Market Report (August 2013).

Ministry of Justice Discussion Paper: Re-evaluation of the Human Rights Protections in New Zealand (October 2000).

New Zealand Employers' Federation and the Equal Employment Opportunities Trust $A$ Guide for Employers on the Human Rights Act 1993 and on Implementing Policies and Programmes for Equal Employment Opportunity (New Zealand Employers' Federation, Wellington, 1993).

New Zealand Human Rights Commission Caring Counts Tautiaki Tika (May 2012).

New Zealand Human Rights Commission Getting a job: An A to Z for employers and employees Pre-employment guidelines (July 2008).

New Zealand Human Rights Commission Tracking Equality at Work (June 2011).

New Zealand Public Service Association Submission to the Transport and Industrial Relations Select Committee by the Public Service Association: Te Pūkenga Here Tikanga Mahi (25 July 2013).

Organisation for Economic Cooperation and Development Economic Surveys: New Zealand (June 2013).

Statistics New Zealand Household Labour Force Survey (June 2013).

Statistics New Zealand Survey of Working Life (December 2012).

H Dissertations

Richard Charles Marshall A Comparison of the Origins and Implementation of the Equal Pay Act 1972 and the Human Rights Commission Act 1977 (Dip Ind Rel Dissertation, Victoria University of Wellington, 1981).

I Internet Resources

International Labour Organization $<$ www.ilo.org $>$.

Marilyn Waring "NZ failure to ratify ILO domestic workers convention "shameful”" (23 June 2010) Institute of Public Policy: An Institute of AUT University <www.ipp.aut.ac.nz>.

Mazengarb's Employment Law (online loose-leaf ed, Lexis Nexis).

Statistics New Zealand “ANZSIC 2006 - industry classification” <www.stats.gov.nz>.

Statistics New Zealand "Household Labour Force Survey" <www.stats.govt.nz>.

J Other Resources 
Committee on the Elimination of Discrimination Against Women, General Recommendation 19, CEDAW/C/L.1/Add.15, 29 January 1992.

International Labour Organization Decent work for domestic workers: C189 \& R201 at a glance (2011). 